Vol. 23, No. 1, pp. 54 88, 2020.

\title{
Review on the Recent Advances in Composite Based Highoutput Piezo-Triboelectric Energy Harvesters
}

\author{
Aamir Rasheed ${ }^{1 *}$, Hyunje Park ${ }^{2 *}$, Min Kyun Sohn², Tae Hyeong Lee², Dae Joon Kang ${ }^{2 \dagger}$ \\ ${ }^{1}$ Interdisciplinary Course of Physics and Chemistry, Sungkyunkwan University, Suwon, 16419, Korea \\ ${ }^{2}$ Department of Physics, Sungkyunkwan University, Suwon, 16419, Korea
}

\section{압전-마찰전기 복합 소재 기반의 고출력 에너지 하베스팅 기술 개발 리뷰}

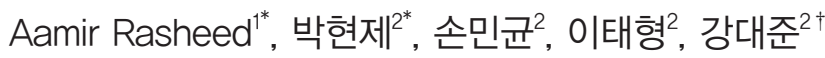 \\ ${ }^{1}$ 성균관대학교 물리화학협동과정 \\ 2성균관대학교 물리학과
}

(Received Febrary 25, 2020; Accepted March 17, 2020)

\begin{abstract}
Global effort has resulted in tremendous progress with energy harvesters that extract mechanical energy from ambient sources, convert it to electrical energy, and use it for systems such as wrist watches, mobile electronic devices, wireless sensor nodes, health monitoring, and biosensors. However, harvesting a single energy source only still pauses a great challenge in driving sustainable and maintenance-free monitoring and sensing devices. Over the last few years, research on high-performance mechanical energy harvesters at the micro and nanoscale has been directed toward the development of hybrid devices that either aim to harvest mechanical energy in addition to other types of energies simultaneously or to exploit multiple mechanisms to more effectively harvest mechanical energy. Herein, we appraise the rational designs for multiple energy harvesting, specifically state-of-the-art hybrid mechanical energy harvesters that employ multiple piezoelectric and triboelectric mechanisms to efficiently harvest mechanical energy. We identify the critical material parameters and device design criteria that lead to high-performance hybrid mechanical energy harvesters. Finally, we address the future perspectives and remaining challenges in the field.
\end{abstract}

Keywords: Piezoelectric energy harvesters, Triboelectric energy harvesters, Hybrid energy harvester, Hybridization mechanisms

${ }^{\dagger}$ Corresponding Author: Dae Joon Kang

E-mail: djkang@skku.edu

"Both authors contributed equally to this work.

54 || 세라미스트 


\section{1. 서 론}

지난 수십 년에 걸쳐 휴대용 컴퓨터, 모바일 통신장 치, 그리고 초고감도 소형센서 기술은 전세계적으로 발 전을 거듭하고 있다. 다양한 기술적 노력들은 마이크로/ 나노 크기의 작동기(actuators), 센서, 그리고 무선 전 송기와 같은 초소형 전자기기의 기능에서 혁신적인 발 전이 이루어져 왔으며, 따라서 보다 효율적이고 안전한 방식으로 생화학적 유해요소 탐지, 실시간 건강 모니터 링, 무선 전송, 그리고 보안 시스템 등이 우리 일상 생 활과 밀접하게 설치 작동하고 있다. ${ }^{1-3)}$ 그럼에도 불구하 고, 센서나 배터리와 같은 분야에서는 지속적으로 향상 되는 에너지 밀도에 비해 부피와 무게, 그리고 수명 등 에서 여전히 기술적 한계를 보여주고 있다. 그러나 최근 기술적 발전은 각종 소형 전자기기의 작동 전력을 낮추 는데 성공하여 현재는 마이크로 와트 $(\mu \mathrm{W})$ 에서 밀리 와 트 $(\mathrm{mW})$ 정도의 전력이 요구될 뿐이다. $\left.{ }^{4-5}\right)$ 한편, 인류에 게 유용한 전기 에너지를 생산해내는 기존의 산업적 방 식에 많은 문제들이 지적되고 있다. 가령, 전기 에너지 를 생산하기 위한 기존의 에너지원, 즉 화석연료나 핵연 료 등은 극심한 환경오염물질을 발생시키므로 인류 사 회가 지향하는 지속 가능한 발전상에 부합하지 않는다. 반면에 친환경 에너지 발전으로 각광을 받고 있는 풍 력 발전이나 수력 발전은 현재까지 요구되는 전력을 충 분한 수준으로 산출해내기 어렵다. 따라서, 친환경적이 고 산업적으로 실현 가능한 수준에서 전기 에너지를 효 과적으로 발생시키는 기술에 대한 연구가 절실한 시점 이라 할 수 있다. 이러한 맥락에서 마이크로/나노 수준 의 재료 공학기술의 발전은 주변의 낭비되는 에너지를 수확하는(harvesting) '에너지 하베스팅 기술(energy harvesting technology)'을 발전시켰다. 이러한 에너 지 하베스터 소자는 손쉬운 작동, 유연소재로의 적용 가 능성, 소자 설계상의 유연성, 그리고 소형 전자기기 작 동에 적합한 출력 성능 등을 근거로 여러 휴대용 착복가 능한(wearable) 전자기기로의 응용이 가능하며, 더 나 아가 각종 소재나 신체와의 통합을 통해 에너지 하베스 터소자는 자가발전 심박조율기, 보청기, 인체 삽입형 소
자, 건축 구조물 진단용 센서 등과 같은 스마트 생체적 합(biocompatible) 소자로의 기술적 응용을 가능하게 한다.

2006년 산화아연 나노와이어( $\mathrm{ZnO}$ nanowire)의 압 전 효과(piezoelectric effect)를 이용한 첫번째 에너 지 하베스터가 개발된 이후로 ${ }^{6}$, 압전 에너지 하베스터 (piezoelectric energy harvesters) ${ }^{7-9)}$, 열전기 에너 지 하베스터(pyroelectric energy harvesters) ${ }^{10-11)}$, 그 리고 마찰전기 에너지 하베스터(triboelectric energy harvesters) ${ }^{12-14)}$ 등과 같은 다양한 유형의 에너지 하베 스터들이 연구되었다. 에너지 하베스터는 일상이나 자 연에서 버려지는 기계적, 열적 ${ }^{15)}$, 화학적 ${ }^{16)}$, 그리고 태양 에너지 ${ }^{5), 15)}$ 등과 같은 에너지원을 특정 에너지 수확 메 커니즘에 입각해 이용가능한 전기 에너지로 전환시키는 소자를 일컫는다. 다양한 에너지원이 존재하나 이중에 서 기계적 에너지는 기후에 독립적이며, 신체 활동, 외 부 진동, 그리고 흐르는 물 등과 같은 자연 현상으로부 터 쉽게 관측되나, 쉽게 다른 에너지로 전환되어 사라진 다. ${ }^{17-19)}$ 이러한 이유로 기계적 에너지 하베스터는 전기 적 에너지를 발생시키기 위해 낭비되는 기계적 에너지 를 수확하는 소자로, 대표적으로 압전 에너지 하베스터 와 마찰전기 에너지 하베스터가 잘 알려져 있다.

마찰전기 대전현상을 응용하여 전기 에너지를 발생 시키는 에너지 하베스터 소자가 2012년 보고된 이후로 ${ }^{12)}$, 그리 긴 시간이 흐르지 않았음에도 이 '마찰전기 에 너지 하베스터'에 대한 연구는 국책연구기관, 대학교 연 구소, 산업체 등 많은 기관에서 다양하고 활발하게 이 루어지고 있다. 마찰전기 에너지 하베스터는 마찰대 전(triboelectrification)과 정전기적 유도 메커니즘으 로 생성되는 전기적 전하들을 이용한다. ${ }^{20-22)}$ 마찰대전 은 서로 다른 두 물질이 접촉하고 분리될 때 전하의 이 동에 의해 전기적으로 대전되는 현상을 일컫는다. 마찰 에 의해 표면 상에 서로 반대 극성의 전하가 생기면, 대 전된 물질의 움직임에 따라 물질 반대편의 양전하와 음 전하가 각각 재분포되어 정전기적 평형을 유지한다. 이 때, 표면에 대전된 전하들은 전위차에 의해 소자의 외부 회로를 따라 이동하면서 전류가 발생한다. 이러한 마찰 
전기 에너지 하베스터는 소자 특성상 가볍고 저렴하며 다양한 물질들이 이용 가능하다는 장점들이 있다. 특히, 보다 높은 출력과 다기능성 구현을 위해 서로 다른 물 성의 물질들을 합성한 여러 복합체들이 이 마찰전기 에 너지 하베스터에 광범위하게 이용되는 실정이다. 최근 에는 마찰전기 에너지 하베스터가 유연하고 착복가능한 소재는 물론, 생체 이식형 칩이나 자가발전 고민감도 센 서 등의 다양한 응용 분야와 접목한 관련 연구가 이루어 지고 있다. ${ }^{22-23)}$ 그러나 본고에서 지속적으로 지적하겠 지만, 이러한 복합체 기반의 마찰전기 에너지 하베스터 는 일반적으로 소자의 대면적화와 저렴한 비용의 제작 이 어려울 뿐만이 아니라, 높은 출력 전압에도 불구하고 낮은 출력 전류밀도를 보인다는 점에서 실재적 응용에 제한적이라는 단점을 지닌다.

한편, 압전 에너지 하베스터는 인가되는 압력에 의해 나타나는 압전 물질의 구조적 변형이 전기적 분극화와 전위차를 발생시키는 압전기(piezoelectricity) 발생 현 상을 이용한다. ${ }^{23)}$ 비록 압전 에너지 하베스터는 현재까 지도 발전 초기 상태에 머무르고 있고 큰 실용성을 보이 고 있지 못하나, 기존의 에너지 하베스터와 소자간의 통 합을 쉽게 허용하고 동시에 독립적인 에너지 수확 메커 니즘으로 전기 에너지를 생산하기 때문에 고출력의 초 소형 전자기기로 유망하다고 할 수 있다. 하지만 다양한 압전 복합체 이용에도 불구하고 낮은 출력 전압으로 충 분한 작동 전력을 공급하지 못하기 때문에 최신형 센서 와 휴대용 전자기기를 작동시키는데 어려움이 있다. ${ }^{24)}$ 반면에, 마찰전기 에너지 하베스터는 출력 전압에서 우 수한 성능을 보이나, 상대적으로 낮은 출력 전류밀도를 갖는다. 또한 우수한 전력 성능에도 불구하고, ${ }^{25-27)}$ 마 찰전기 에너지 하베스터의 복잡하고 비효율적인 공정 과정은 하베스팅 기술의 광범위한 응용적 측면에서 매 우 제한적이다. ${ }^{28)}$ 게다가, 정전기적 전하 분리를 유지하 기 위해 전극물질 사이에 일종의 공기층 유지가 소자 내 에서 요구되며, ${ }^{29)}$ (특히, 슬라이딩 방식에서) 마찰대전 층 사이에서 마찰로 인한 방열은 출력 에너지 손실을 야 기한다. ${ }^{30)}$ 여기서 문제의 핵심은 높은 출력성능을 달성 하기 위해 단일 에너지 수확 메커니즘을 이용하는 에너
지 하베스팅 소자는 저마다 기술적 문제에 봉착한다는 것이다.

이에 여러 연구들은 압전 물질과 마찰대전 물질의 복 합체를 기반으로 다양한 에너지 원천을 동시다발적으 로 수확하여 전체적인 출력성능을 높이는 방안을 제시 한다. ${ }^{31-33)}$ 본고에서 사용할 '하이브리드(hybrid)'의 의미 는 최소 둘 이상의 서로 독립적인 에너지 수확 메커니즘 이 소자 내에서 병립적으로 실현되는 것이다. 출력 성능 향상이라는 근본적인 취지에 알맞게 다양한 하이브리드 에너지 하베스터들이 보고되었다. 2009년 최초로 태양 에너지와 기계적 에너지를 동시에 수확하는 하이브리드 소자가 보고된 이후로 ${ }^{34)}$, 압전 효과 ${ }^{38-39)}$, 마찰대전 ${ }^{40-41)}$, 태양 에너지 ${ }^{5)}$, 전자기 에너지 ${ }^{42-43)}$, 진동 에너지 ${ }^{44-45)}$, 자 기적 에너지 발생 ${ }^{45}$ 등의 다양한 원리와 기술들이 하베 스팅 소자의 하이브리드화를 위해 연구되었다. ${ }^{34-37)}$ 비 록 에너지 수확 메커니즘들은 저마다 분명한 차이가 있 지만 작동 메커니즘간 공통된 특징이 있다면 하이브리 드 에너지 하베스터로 응용이 가능하다. ${ }^{33)}$ 예를 들어 압 전 에너지 하베스터의 단일 메커니즘에 의하면 압전효 과 층은 전압을 발생시키기 위해 변형된 이후에 원상태 로 돌아온다. 이 가역적인 과정에서는 기판과 전극 사이 에 반복적으로 발생하는 물리적 접촉이 있는데, 이때 발 생하는 마찰대전 효과를 적절한 방식으로 에너지 하베 스터 소자 상에 유도할 수 있다. 즉, 상이한 두 메커니즘 에 근거한 서로 다른 물질들의 합성을 통해 에너지 하베 스터 소자로 이용이 가능하다면 전기적 출력 신호의 동 시적인 산출이 가능한 것이다.

압전 효과와 마찰전기 효과에 기반한 두 유형의 에너 지 하베스터들의 소자상 통합은 이미 광범위하게 연구 되었는데, 그 이유는 압전-마찰전기 복합체를 타 복합 체에 비해 손쉽고 효율적으로 합성할 수 있기 때문이다. 이러한 압전-마찰전기 복합체 기반의 하이브리드 에너 지 하베스터는 결과적으로 단일 메커니즘에 기반한 소 자보다 우수한 출력 성능을 실현시킬 수 있다. 이러한 하이브리드 시스템의 압착-분리 주기에서 압전 효과 에 의한 고출력 전류와 마찰전기에 의한 고출력 전압이 단순한 합이 아닌 시너지 효과로서 발생하는데, 앞으로 


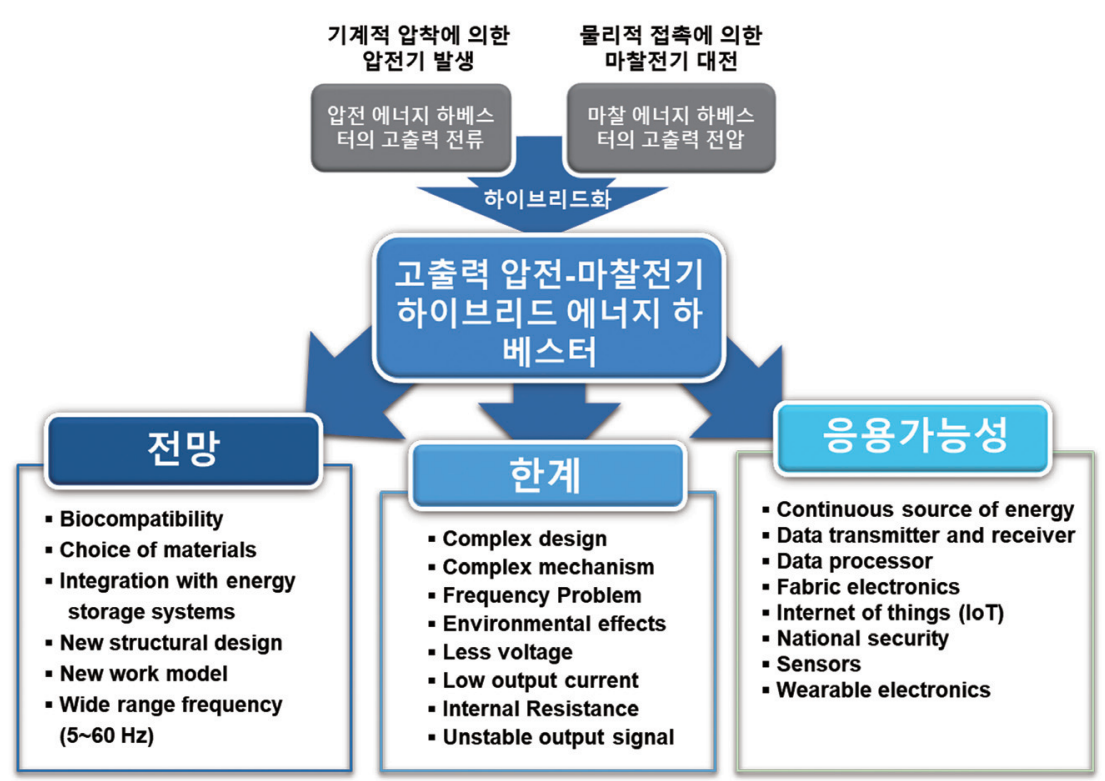

그림 1. 본고에 대한 개괄: 압전-마찰전기 에너지 하베스터, 특징, 문제, 응용, 전망.

설명할 임피던스 일치(matched impedance), 접촉면 의 극대화, 두 에너지 하베스터의 작동 진동수(working frequency) 등의 주요 요소들을 세심하게 조율한다면 단일 하이브리드 소자 내에서 우수한 출력 성능을 구현 할 수 있다. ${ }^{32}$

본고에서는 복합체 기반의 다양한 하이브리드 에너지 하베스터들 중에서, 압전기 발생과 마찰전기 발생의 두 에너지 수확 메커니즘을 결합한 '압전-마찰전기 하이브 리드 에너지 하베스터'에 대한 다양한 연구와 한계를 검 토하고자 한다. 압전-마찰전기 복합체 기반의 하이브 리드 에너지 하베스터는 각자의 기술적 단점들, 즉 압전 에너지 하베스터에서의 낮은 출력전압과 마찰전기 에너 지 하베스터에서의 낮은 출력 전류밀도의 문제를 상호 보완적으로 극복할 수 있다. 기본적으로 두 메커니즘이 외부 힘의 인가에 따른 물질의 전기적 반응(물질 구조의 변형에 따른 분극화와 서로 다른 물질의 접촉에 따른 전 기적 대전)을 이용한다는 점에서, 에너지를 수확하는 서 로 다른 방식이 한 소자 내에서 병립적으로 실현가능하 다는 것은 쉽게 이해될 수 있다. 비록 압전-마찰전기 하 이브리드 에너지 하베스터의 고출력 성능이 여러 연구 를 통해 증명되었으나 ${ }^{46-50)}$, 현재까지도 최적의 소자구
조 설계, 전하의 분배, 외부 힘에 의한 전하 교환, 상이 한 두 메커니즘이 발생시키는 시너지 효과, 고출력에 기 여하는 핵심 요소들 등은 여전히 불만족스러운 이해 가 운데 놓여있다. 이러한 기술적 흐름에서 이 분야의 최근 성취와 제기된 문제는 잠재적 연구자들로 하여금 더 나 은 이해와 연구 동기를 제공하고 안내하기 위해 자세히 논의될 필요가 있다. 이와 같은 이유로, 최근까지 발전 한 압전-마찰전기 복합체를 이용하는 하이브리드 에너 지 하베스팅 기술에 대한 시의적절한 검토가 요구되는 것이다.

본고에서는 압전-마찰전기 복합체 기반의 하이브리 드 에너지 하베스팅 기술에 대한 최근 기술 동향에 대 해 서술하고자 하며, 특히 이 분야에서 핵심적인 문제 들을 개괄하고자 한다. 우선, 압전 에너지 하베스터와 마찰전기 에너지 하베스터의 기본적인 개념과 작동 방 식들을 살펴본 이후에, 압전-마찰전기 하이브리드화 (hybridzation) 연구의 최근 연구 결과들을 살펴볼 것이 다. 동시에 소자 설계와 복합체 이용 등에 따른 출력 성 능에 관한 요약을 시도할 것이다. 그리고 하이브리드 에 너지 하베스터의 출력 성능을 결정하는 요소들은 소자 의 응용과 제작과정에 대한 고려 속에서 논의될 것이다. 


\section{특 집 ㅁamir Rasheed, 박현제, 손민균, 이태형, 강대준}

이상으로 그림 1 은 언급한 내용에 관한 압전-마찰전기 하이브리드 에너지 하베스터의 향후 전망과 문제 등을 요약한다.

\section{2. 압전 에너지 하베스터}

\section{1. 압전 효과를 이용한 전력 생산}

압전 효과의 본성은 외부 힘에 의한 물질 속의 쌍극 자 모멘트 유도에 기반한다. 쌍극자 모멘트는 산화아연 (Zinc oxide, $\mathrm{ZnO}$ ), 타이타늄산바륨(Barium titanate, $\mathrm{BTO})$, 타이타늄산지르콘산연(Lead zirconate titanate, PZT)등과 같은 물질의 결정 구조에서 비대칭 적 전하 분포로 인해 발생하거나 물과 같은 몇몇 분자 그룹에서는 분자 자체가 이동하여 내재적으로 유발된 다. 외부 힘이나 압력이 인가될 때, 내부 구조는 변형이 일어나는데, 이때 이온들은 본래의 자리를 이탈하면서 (dislodged) 압전 전위를 발생시킨다. 부가저항이 이 시 스템에 연결되면, 발생한 전위차로 인해 전자들은 저항 을 거쳐 외부 회로를 따라 움직여 정전기적 평형에 도달 한다. ${ }^{51-52)}$ 이 방식에서 페르미 준위 차이의 증가로 인해 교류 전류가 발생하는데 ${ }^{53)}$, 이것이 압전 효과에 의한 전 기적 출력신호 발생의 기본적 메커니즘이라 할 수 있다. 원리적으로, 압전 에너지 하베스터의 성능을 개선시기 키 위해서는 두 요소, 즉, 물질 선택과 소자의 제작 설계 에 주의를 기울어야 한다.

\section{2. 산화아연을 이용한 압전 에너지 하베스터}

$\mathrm{BTO}^{56-58)}, \mathrm{ZnO}^{59-61)}, \mathrm{PZT}^{62-64)}$, 폴리비닐 리덴플루 오라이드(polyvinylidene difluoride, $\mathrm{PVDF})^{65-70)}$, 그 리고 이상 물질들을 조합한 여러 압전 물질들(예를 들 어, $\mathrm{ZnO}$ 나노입자들과 $\mathrm{PVDF}$ 스펀지의 합성 $\left.{ }^{69}\right)$ 은 다양 한 형태의 나노구조체 합성과 함께 압전 효과로 인한 전 기적 신호 발생 현상이 연구되었다. $\mathrm{PZT}$ 와 BTO는 우수 한 기계적 안정성과 높은 압전 변형 계수(piezoelectric strain constant)와 같은 흥미로운 압전 특성을 가진 것 으로 알려져 있다. 그러나, 이러한 물질들은 합성과정에 서의 여러 어려움으로 인해 압전기 발생의 상용화에 있
어 단점을 지닌다. ${ }^{58-59)}$ 특히, 취성(brittle)한 성질로 인 해 장기간에 걸친 반복적인 기계적 변형을 견디지 못하 기에 압전 에너지 하베스터는 기계적 내구도의 제한으 로 광범위한 응용에 어려움을 겪는다.

여러 압전 물질들 중에서, 산화아연 $(\mathrm{ZnO})$ 은 압전 효 과를 내보이는 대표적인 반도체 물질로, 고유 물성을 응 용하기 위한 다양한 소자와 합성법 등이 연구되었다. 특 히, 에너지 하베스팅에 있어 이 물질은 상당한 주목을 받는데, 대개 표면적 증대를 위해 $\mathrm{ZnO}$ 나노와이어나 나 노조각 등으로의 합성을 통해 이용된다. $\mathrm{ZnO}$ 나노와이 어 기반의 압전 에너지 하베스터는 소자 작동을 위한 진 동수가 수 $\mathrm{Hz}$ 에서 수 $\mathrm{MHz}$ 에 이르는 넓은 범위를 갖기 때문에 바람, 진동, 신체 활동 등에서 발생하는 기계적

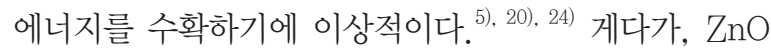
기반의 압전 에너지 하베스터는 무독성과 생체적합성으 로 인해 환경친화적이다. ${ }^{55)}$ 이로 인해 $\mathrm{ZnO}$ 나노구조체 의 압전/반도체 특성들은 나노 수준의 에너지 하베스터 제작에 이용된다.

압전 효과를 이용한 에너지 하베스터 기술 발전에 관 하여, 태국의 테크놀로지 아시아 연구소의 Dakua 박 사 연구팀은 다양한 압전 물질 이용에 따른 압전 에 너지 하베스터가 어떠한 방식으로 응용가능한지 면밀 하게 검토하였다. ${ }^{48)}$ 이들의 연구 및 조사에 따르면 넓 은 범위의 작동 진동수를 지니는 압전 물질의 이용 이 보편화되면서 해당 물질을 사용한 에너지 하베스 터 제작기술 개발과 이를 응용한 초소형 정밀기계 기술 (microelectromechanical system, MEMS)은 2013년 까지 상당한 수준으로 발전하였다. 세라믹과 고분자 물 질은 주로 압전 효과를 통한 에너지 수확에 이용될 수 있으며, 이러한 물질들의 나노구조체는 MEMS 기반의 에너지 하베스팅에서 이점을 내보인다.

지난 수십년에 걸쳐, $\mathrm{ZnO}$ 의 압전 특성, 즉 띠틈(band gap), 전기화학적 결합계수와 압전 변형계수 등이 다 른 압전 물질과 함께 비교 및 연구되었다. 표 1은 여기 에 대한 요약을 보여준다. $\mathrm{ZnO}$ 나노구조체를 이용하 는 압전 에너지 하베스터는 이후로 '압전 나노발전기 (piezoelectric nanogenerator)'로 알려지게 되었으며, 
표 1. $\mathrm{ZnO}$ 의 압전 특성들.

\begin{tabular}{c|c}
\hline 압전 특성 & 값 (단위) \\
띠틈(band gap $)^{71)}$ & $3.37(\mathrm{eV})$ \\
\hline 전기화학 결합계수 $\left(\mathrm{d}_{33}\right)^{46)}$ & $12\left(\mathrm{pCN}^{-1}\right)$ \\
\hline 탄성 상수 $\left(\mathrm{C}_{33}\right)^{72)}$ & 210.9 \\
\hline 압전 상수 $\left(\mathrm{e}_{33}\right)^{73)}$ & $1.34(-0.57)\left(\mathrm{Cm}^{-2}\right)$ \\
\hline
\end{tabular}

압전기 발생을 위한 전형적인 에너지 하베스팅 소자 설 계가 여기에 기반한다. 이 압전 나노발전기는 기계적 압 착이나 응력을 통해 역학적 에너지를 전기적 에너지로 변환시킬 수 있다.

2006년 Zhong Lin Wang 교수 연구팀에서는 $\mathrm{ZnO}$ 나노와이어의 압전/반도체적 특성을 이용하여 기계적 에너지를 압전기 발생으로 이용하는 최초의 압전 나노 발전기를 보고하였다. ${ }^{6)}$ 특정 방향으로 정렬된 $\mathrm{ZnO}$ 나 노와이어는 원자힘현미경(atomic force microscopy, $\mathrm{AFM})$ 의 백금 코팅된 탐침의 반복적인 접촉으로 인해 구부러진다. 변형력(strain)이 가해진 $\mathrm{ZnO}$ 나노와이 어에서는 이때 탐침과 $\mathrm{ZnO}$ 나노와이어 끝부분 사이에 쇼트키 접촉(Schottky contact)이 형성된다. 초기에, $\mathrm{AFM}$ 탐침은 나노와이어의 올곧은 부분과 접촉하여 양 의 전위를 가진다. 이 경우, 백금-산화아연 계면에서의 바이어스 전압(bias voltage)은 음의 방향이 되며, 역 바이어스 쇼트키 다이오드(reverse-biased Schottky diode)는 접합 부분을 거치기 위해 미량의 전류를 허 용한다. AFM 탐침이 나노와이어의 압착된 부분과 접 촉할 때 순방향 바이어스 쇼트키 다이오드(forwardbiased Schottky diode)가 최대 전류를 허용하는데, 그

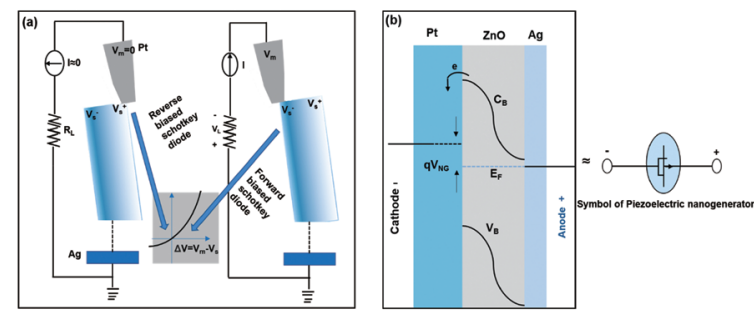

그림 2. (a) $\mathrm{ZnO}$ 나노와이어 상단부를 주사하는 AFM 탐침을 이용 한 압전 에너지 하베스터의 작동원리. (b) 해당 에너지 하베 스터의 압전 전위, 출력 전압, 그리고 에너지 밴드 다이어 그램 ${ }^{82)}$
림 2(a)와 (b)에서 보여지는 것처럼 높은 전류 피크가 관 측된다. 참고로, 금속과 반도체 물질 사이의 쇼트키 장 벽(Schottky barrier)은 전기적 에너지 발생에 핵심적 이다. ${ }^{74-75)}$ 최초의 압전 에너지 하베스터 이후에 여러 관련 연구들이 진행되었는데, 그 중에서는 폴리에틸렌 (polyethylene, $\mathrm{PE}$ ) 유연기판 위에 수평으로 속박된 단 일 $\mathrm{ZnO}$ 나노와이어를 이용한 새로운 에너지 하베스터 가 보고되기도 하였다. ${ }^{23), 76}$

이민백 교수 연구팀은 유독성의 수은이온 $\left(\mathrm{Hg}^{2+}\right)$ 을 감 지하는 센서가 나노발전기에 의해 자가발전 시스템으 로 작동 가능하다는 것을 증명하였다. ${ }^{77)}$ 이들은 감지 센서를 위해 $\mathrm{ZnO}$ 나노와이어와 단일벽 탄소나노튜브 (single-walled carbon nanotubes)를 이용한 자가발 전 에너지 하베스터를 개발하였다. 축전기와 감지 신호 로서의 발광다이오드는 각각 에너지 하베스터에 통합되 어서 수은 이온으로 오염된 물속에서 해당 이온만을 선 별적으로 감지하는 것이 가능함을 보였다. 소자 설계에 있어서, 10 층의 $\mathrm{ZnO}$ 나노와이어와 은 박막은 유연기판 위에 에너지 하베스터의 효율을 높이기 위해 증착 되었 고, 단일장벽 탄소나노튜브 기반의 FET(field emission transistor) 소자는 수은 이온 센서로서 이용되었다. 수 은이온의 전기적 포텔션과 단일장벽 탄소나노튜브 사이 의 차이는 부착된 $\mathrm{LED}$ 를 전등시키었기에 센서 작동으 로서 성공적인 스위치 역할을 하였다.

성균관대학교 김상우 교수 연구팀은 셀룰로오스 종이 기반의 압전 에너지 하베스터에 대한 연구를 실시하였 다. ${ }^{78)}$ 셀룰로오스는 가볍고, 접을 수 있으며, 또한 손쉽 게 구할 수 있는 재료이자 낮은 열팽창 계수 $\left(\sim 10^{-5} \mathrm{~K}^{-1}\right)$ 로 인해 열적으로 안정적인 특성을 갖는다. 수용액 합 성 방식을 통해 $\mathrm{ZnO}$ 나노막대기(nanorods)가 금과 알 루미늄이 코팅된 셀룰로오스 기판 위에 합성되었고 소 자의 가장자리들은 물리적 화학적 손상을 방지하기 위 해 봉인되었다. 관측된 바에 따르면 출력 전류밀도는 $\sim 2 \mu \mathrm{Acm}^{-2}$ 이다. 일반적으로 플라스틱(고분자) 기반의 에너지 하베스터는 열적으로 유도되는 응력(thermal induced-stress)으로 인해 불안전한 전기적 출력신호 를 발생시키는데, 셀룰로오스의 낮은 열팽창 계수는 이 


\section{특 집 ㅁ Aamir Rasheed, 박현제, 손민균, 이태형, 강대준}

러한 문제를 극복하기에 높은 출력신호를 보다 안정적 으로 산출하는 것이 가능하다. 소자 설계에 있어서 이들 은 전기를 발생시키기 위해 주로 쇼트키 접촉을 이용하 였는데, 이러한 설계 구조상의 특징을 이용하여 최근까 지도 샌드위치 구조 등과 같은 다양한 설계를 지니는 에 너지 하베스터들에 대한 연구가 진행되고 있다. ${ }^{79-31)}$

\section{3. 쇼트키 다이오드를 이용한 에너지 하베스터}

쇼트키 다이오드 기반 에너지 하베스터는 반도체 특 성을 보이는 $\mathrm{ZnO}$ 나노와이어의 한 끝 부분은 다른 끝 부분으로부터 나오는 전자들을 모으기 위해 금속과 접 촉되어 있는데, 이는 전자들이 금속-반도체 계면을 통 과하지 못하기 때문이다. ${ }^{47)}$ 금속과 $\mathrm{N}$ 유형 반도체인 $\mathrm{ZnO}$ 사이에 쇼트키 장벽을 형성하기 위해, $\mathrm{ZnO}$ 의 전자 친화도는 금속의 일함수보다 낮아야만 한다. ${ }^{20)}$ 작동원리 에서, 응력이 나노와이어에 가해지면, 발생한 압전 전위 차는 전자들이 나노와이어의 한 끝에서 다른 끝으로 흐 르게 하며, 이러한 전자들은 접촉 장벽에서 축적된다. 응력이 제거되면 전자들의 흐름은 회로를 따라 반대 방 향으로 흐른다. 이 방식에서 전기적 전류 펄스가 관측된 다. (본고에서는 두 종류의 쇼트키 다이오드 기반의 에 너지 하베스터들, 즉, 측면 나노와이어 쇼트키 다이오드 와 수직 쇼트키 다이오드만을 한정하여 고려하고 있다.)

\section{3. 마찰전기 에너지 하베스터}

\section{1. 기본 메커니즘}

고대 그리스에서부터 알려진 마찰전기의 발생은 인간 생명, 기계를 통한 제품 생산, 그리고 전자제품의 회로 등에 심각한 손상을 가할 수 있다는 이유를 들어 일반적 으로 원치 않는 효과로 알려져 있다. ${ }^{83)}$ 그러나, 자연 속 에 만연한 이 마찰전기는 에너지 수확의 관점에서 중요 한 역할을 할 수 있다. 마찰전기의 발생은 특정 물질에 제약 받지 않기에 다양한 물질들이 고유의 목적에 따라 이용 가능하다. 이용 물질들의 표면에 형성되는 마찰 전 하의 분극 정도는 일반적으로 알려진 것처럼 마찰전기 표(Triboelectric Series)에 의해 결정되며, 여기에 따
른 마찰대전층 물질의 선택은 우수한 출력을 위해 필수 적이다. 일반적으로, 마찰전기는 서로 다른 전자 친화도 를 가진 두 물질들의 접촉, 미끄러짐, 문지름 등에 의해 발생한다. 에너지 하베스터의 기본적인 개념은 주변의 역학적 에너지를 전기적 에너지로 변환시키는 것이기에 이러한 현상을 응용한 소자는 마찰전기 에너지 하베스 터로 불리운다.

2012년 Zhong Lin Wang 교수 연구팀에 의해 PET 필름(polyethylene terephthalate film)과 캡톤 필름 (Kapton film)을 이용한 첫 번째 마찰전기 에너지 하베 스터가 개발되었다. ${ }^{83)}$ 앞서 언급한 것처럼 마찰전기 에 너지 하베스터의 우수한 출력 성능을 위한 물질 선택은 마찰전기표에서 나타나는 전자 친화도에 기반한다. 마 찰전기 에너지 하베스터를 위한 다양한 물질들이 문헌 속에서 보고되었으며, 이러한 물질들은 일반적으로 음 과 양의 마찰전기 친화도에 따라 배열된다. ${ }^{85)}$ 보고된 바 에 따르면, 두 물질 간의 전자 친화도의 차이가 클수록, 출력 전압과 전력이 높아진다. 표면 전하밀도, 일함수, 전자 공여 포텐셜(electron donation potential) 등은 마찰전기 에너지 하베스터의 출력 성능에 영향을 주기 위한 핵심 요소이다. 그림 3 는 마찰전기 에너지 하베스 터를 통해 기계적 에너지를 전기적 에너지로 변환시키 는 4 가지의 기본 작동 방식을 보여준다. ${ }^{82}$

\section{2. 마찰전기 에너지 하베스터의 4 가지 작동 방식}

\subsection{1. 수직 접촉-분리 방식}

수직 접촉-분리 방식은 마찰전기 에너지 하베스터의 단순한 형태로서, 양 전극들에 부착된 서로 다른 두 절 연물질이 약간의 간격으로 분리된 소자 구성에서 작동 한다. 금속류는 적합한 전자 공여 전위뿐만이 아니라 자 유전자도 가지기에, 마찰전기 에너지 하베스터에서 마 찰전기 층으로서 이용될 수 있다. 양 표면이 물리적 접 촉을 할 때, 표면 물질의 일함수/전자 친화도로 인해 전 하 재분배가 각각 일어난다 (접촉 단계). 두 평면이 서로 멀어진다면, 그림 $3 \mathrm{a}$ 에서 보여지는 것처럼, 발생한 정전 기 장의 균형을 유지하기 위해 전자들이 외부 회로를 따 


\section{Working modes of triboelectric energy harvesters}

(a)

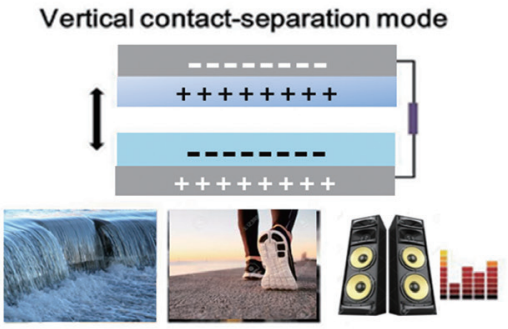

(c) Freestanding triboelectric-layer mode

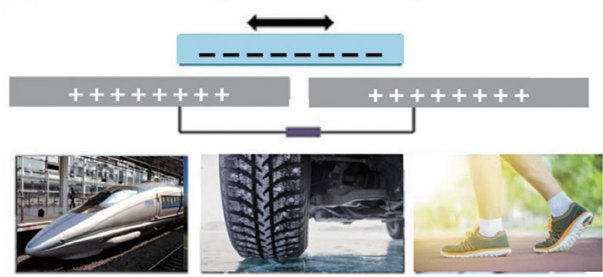

(b) Lateral sliding mode

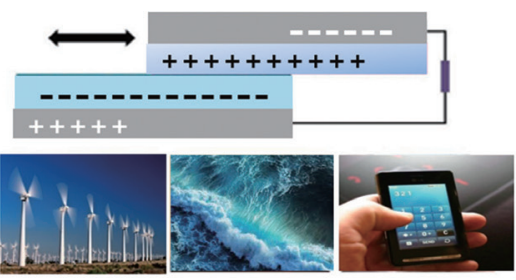

(d) Single-electrode mode

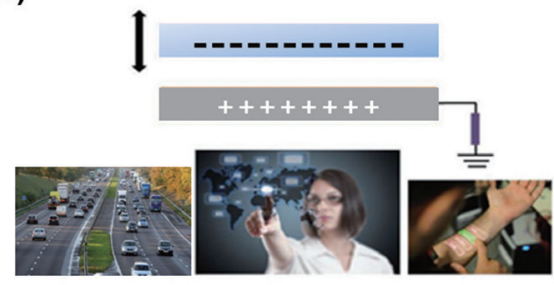

그림 3. 마찰전기 에너지 하베스터의 4가지 모드: (a) 수직적 접촉-분리 모드, (b) 측면 슬라이딩 모드, (c) 단독 (free-standing) 마찰전기층 모드, 그리고 (d) 단일전극 모드 ${ }^{89}$

라 한 전극에서 다른 전극으로 움직인다 (분리 단계). 증 가한 간격이 원상태로 돌아오면, 전자들은 전압 생산 과 정을 마치기 위해 다시 반대방향으로 흐른다. ${ }^{27}$

\subsection{2. 측면/평면상 슬라이딩 방식}

측면 슬라이딩 방식에서 전자 친화도의 차이가 큰 두 평행한 마찰전기 층은 평면과 평행한 방향의 외부 힘에 의해 서로 미끄러진다. 두 평면의 슬라이딩은 각각의 표 면에서 마찰 전하를 유도하며 미끄러지는 방향의 측면 으로 분극화를 발생시킨다. 초기 단계에서 두 평면들은 중성 전하를 가지나, 그림 $3 \mathrm{~b}$ 에 나타나는 것처럼 평행하 게 미끄러지면서 변위가 발생한다. 이 전하 교란(charge disturbance)으로 인해, 두 표면을 연결시키는 전극 사 이에서 전위차가 발생한다. 전기화학적 전위 균형을 맞 추기 위해, 전자들은 낮은 전자 친화도를 가진 표면에서 높은 전자 친화도를 가진 표면으로 이동한다. 이 주기적 인 변위와 연결-단절 메커니즘은 교류 출력 전압을 발 생시킨다. 이러한 방식에서 슬라이딩은 평면, 원기둥, 그리고 원형 회전과 같은 서로 다른 방향에서 나타날 수
있다. 출력 효율을 증가시키기 위해 선형 격자, 원형, 그 리고 개별적으로 분절된 소자 설계는 다양한 전하 분리 주기들을 실현시키는 방식에 이용가능하다. 또한, 이 경 우에서 전하 교환은 각각의 격자 또는 부분들로 인해 여 러 번 반복적으로 발생할 수 있다. ${ }^{86)}$

\subsection{3. 단독(free-standing) 마찰대전 방식}

마찰전기 에너지 하베스터의 단독 방식은 보통 옷감, 장갑, 그리고 신발과 같이 자유롭게 움직이는 물체들로 부터 역학적 에너지를 수확하기 위해 이용된다. 자유로 이 움직이는 물체들은 공기나 땅과 접촉하는데, 이때 전 자 친화도의 차이에 따라 접촉면에서 마찰대전이 발생 하여 결과적으로 전기적 출력 신호를 발생시킨다. 이 단 독 방식에서 물체들은 오랜 시간에 걸쳐 전하를 유지할 수 있는데, 대전된 전하가 유지되는 동안 최대 전하 밀 도에 따라 추가적인 마찰 또는 접촉의 필요가 없어진 다. 자유로이 움직이는 물체들은 단독 마찰전기 층의 역 할을 한다. 이 방식의 마찰전기 에너지 하베스터는 소 자 설계에서 대칭적인 두 전극을 가지며 움직이는 물체 
와 동일한 크기의 간격을 유지한다. 이 전극들은 절연 표면에 연결되어 있어서 단독 마찰전기 층이 전극들로 부터 가까워지거나 멀어질 때, 전자 흐름을 발생시키는 비대칭적인 전위가 발생한다. 결과적으로, 교류 전압이 전자의 진동 운동에 의해 전극 사이로 발생하는 것이다 (그림 3). ${ }^{87)}$

\subsection{4. 단일전극 방식}

접촉(-)슬라이딩과 접촉-분리 방식은 계단 또는 땅 위를 걷거나, 자동차의 움직임, 또는 터치 스크린으로부 터 미끄러지는 손가락 등과 같은 과정에서 얻어지는 역 학적 에너지를 수확하기에 적합하지 않다. 왜냐하면 이 러한 경우에 마찰전기 에너지 하베스터는 소자 설계상 의 제약으로 인해 부가저항과의 연결이 쉽지 않기 때문 이다. 이 문제를 극복하기 위해 전극들이 서로 연결되지 않은 방식 하에서 마찰전기 발전층이 자유롭게 움직일 수 있는 새로운 방식이 고안되었다. 단일전극 방식에서, 접지 또는 다른 도체가 전자들을 제공하기 위해 하부 전 극으로 이용된다. 외부 물체는 상보적인 마찰전기 층으 로서 접지된 하부 전극과 접촉한다. 결과적으로 주기적 인 미끄러짐과 접촉-분리에서 접지와 전극 사이에 교류 전류를 발생하는 것이다. 비록 이 방식에서 정전기적 차 폐(electrostatic screening)가 발생하지만, 그림 3d에 서 나타나는 것처럼 전하들은 마찰전기 발전층의 수직 또는 수평으로 자유롭게 이동할 수 있다. ${ }^{88)}$

이상의 작동 방식들 중에서 접촉-분리 방식은 다양한 환경에서 발생하는 기계적 에너지를 적절한 방식으로 수확할 수 있기 때문에 자주 이용된다. 그러나, 다른 작 동 방식들과 비교해보면 작동 진동수는 상당히 높다. ${ }^{90-}$ 91) 게다가, 마찰전기 에너지 하베스터의 출력 전류는 높 은 부가저항으로 인해 낮은 수치를 보인다. 이러한 단 점을 개선하기 위해 그래핀 등의 2 차원 평면 물질은 소 자의 부가저항을 낮추기 위해 이용되었다. 예를 들어, 그래핀은 표면의 일함수나 페르미 준위를 쉽게 제어할 수 있는 특성뿐만 아니라 우수한 전기적, 기계적 특성 을 지니기에 우수한 출력과 내구성을 가지고 있어 에너 지 하베스터 소자의 마찰전기/전극 물질로 이용이 가능
하다. ${ }^{92)}$

이처럼 높은 출력신호 이외에도 내구도나 유연성 등 의 다양한 기능들을 하이브리드 소자에 실현시키기 위 해서는 이에 부합하는 여러 화학적 물질들을 적절한 방 식으로 혼합하여 이용할 필요가 있다. 그래핀과 같이 다 양한 특성을 지니는 물질을 단일적으로 이용하기보다 여러 물질과의 합성과정을 통해 복합체 기반의 하베스 터 소자를 구성하는 것은 좋은 대안이 될 수 있다. 그 예 로, $\mathrm{ZnO}$ 나노구조체를 해당 물질의 기계적 특성 강화와 마찰대전 현상을 유도하기 위해 다양한 마찰전기 물질 을 수열 합성법 (hydrothermal method) 등을 통해 복 합체를 제작하는 방식은 이미 널리 알려져 있다. 표면의 다기능화를 위해 그래핀과 같은 물질을 유기물 혼합물 에 담그는(dipping) 수용액 방식을 선택한다면 손쉬운 방식으로 복합체를 제작하여 여러 물성을 합리적인 방 식에서 소자 내에 구현하는 것이 가능하다. 화학적 기능 화 이외에도, 마이크로 수준의 피라미드나 원기둥과 같 은 주기적인 마이크로/나노 구조체를 이용한 마찰전기 표면 엔지니어링은 마찰전기 에너지 하베스터의 출력 성능을 효과적으로 높이는데 고려할 만한 전략이라 할 수 있다. ${ }^{93)}$

\section{4. 복합체 기반의 하이브리드형 에너지 하베스터}

\section{1. 다양한 하이브리드 에너지 하베스터와 주요 매개변수들}

단일 에너지 수확 메커니즘에 의존하는 에너지 하베 스터는 수확 가능한 에너지를 낭비하는 경향이 있다. ${ }^{24)}$ 94-98) 예를 들어, 태양전지 소자는 빛을 전기로 변환시킨 다. 그러나, 일반적으로 태양빛에 의한 열은 수확되지 않으며, 떨어지는 빗방울에 의한 역학적 에너지도 마찬 가지로 낭비될 뿐이다. 또한 현재 수준에서 단일 에너지 수확 메커니즘에 기반한 에너지 하베스터는 여전히 다 양한 휴대용 전자기기를 작동시키기에 불충분한 전력을 공급할 뿐이라는 점에서 출력 성능 향상을 위해 둘 이 상의 에너지원을 동시적으로 수확하는 기술에 대한 흥 미가 급격히 증가하기 시작하였다. 이러한 맥락에서 서 
표 2. 하이브리드 에너지 하베스터들의 최근 발전.

\begin{tabular}{|c|c|c|}
\hline 보고 연도 & 수확 에너지 종류 & 출력 성능 \\
\hline $2009^{34)}$ & 태양광 에너지와 기계적 에너지 & $\begin{array}{l}\text { 소자 회로의 병렬 연결: } 0.591 \mathrm{~V}, 45.5 \mu \mathrm{Acm}^{-2} \\
\text { 소자 회로의 직렬 연결: } 0.60 \mathrm{~V}, 6.9 \mu \mathrm{Acm}^{-2}\end{array}$ \\
\hline $2010^{99)}$ & 태양광 에너지와 음파 에너지 & $\sim 6 \mathrm{mV}, \sim 57 \mathrm{Na}$ \\
\hline $2011^{101)}$ & 태양광 에너지와 기계적 에너지 & $0.234 \mathrm{~V}, 34.6 \mu \mathrm{Wcm}^{-2}, 140 \mu \mathrm{Acm}^{-2}$ \\
\hline $2012^{102)}$ & 태양광 에너지와 기계적 에너지 & $3.3 \mathrm{~V}, 7.65 \mu \mathrm{A}$ \\
\hline $2013^{103)}$ & 태양광 에너지와 기계적 에너지 & $0.8 \mathrm{~V}$ \\
\hline $2013^{104)}$ & 태양광 에너지, 열 에너지, 기계적 에너지 & $15 \mathrm{~V}$ \\
\hline $2013^{105)}$ & 마찰전기 에너지와 태양광 에너지 & $12 \mathrm{~V}, 17.4 \mathrm{~mA}$ \\
\hline $2014^{11)}$ & 압전 에너지와 열전 에너지 & $1.4 \mathrm{~V}$ \\
\hline $2014^{16)}$ & 태양광 에너지와 화학에너지 & $90 \mathrm{~V}, 0.5 \mathrm{mAm}^{-2}$ \\
\hline $2015^{106)}$ & 태양광 에너지와 기계적 에너지 & $7 \mathrm{~V}, 128 \mathrm{Na}, 0.27 \mu \mathrm{W}$ \\
\hline $2015^{107)}$ & 태양광 에너지와 기계적 에너지 & $20 \mathrm{~V}, 86 \mathrm{mWm}^{-2}, 25.9 \mathrm{mAcm}^{-2}$ \\
\hline $2015^{108)}$ & 태양광 에너지와 기계적 에너지 & $1.9 \mathrm{~V}$ \\
\hline $2016^{109)}$ & 전자기 에너지와 마찰전기 에너지 & $5 \mathrm{~V}$ \\
\hline $2016^{110)}$ & 수력 에너지와 태양광 에너지 & $28.14 \mu \mathrm{W}$ \\
\hline $2017^{111)}$ & 열 에너지와 기계적 에너지 & $4.0 \mathrm{~V}, 1.6 \mathrm{~mW}$ \\
\hline $2017^{112)}$ & 열 에너지와 기계적 에너지 & $1.09 \mathrm{~V}, 1.17 \mathrm{mAcm}^{-2}$ \\
\hline $2018^{113)}$ & 열 에너지와 기계적 에너지 & $\sim 150 \mathrm{nA}$ \\
\hline $2019^{114)}$ & 전자기 에너지와 마찰전기 에너지 & $20 \mathrm{~V}, 300 \mathrm{nA}$ \\
\hline
\end{tabular}

로 다른 에너지 수확 메커니즘을 구현하는 여러 물질들 을 합성하여 한 소자에 구현시키고자 하는 기술적 시도 들이 있어 왔다. 기존 에너지 하베스팅 소자가 맞닥뜨리 는 제한적인 출력 성능의 문제를 획기적으로 극복하기 위해 에너지 하베스팅 기술은 이른바, '하이브리드 에너 지 하베스터' 라는 새로운 방향성과 함께 나타나기 시작 한 것이다.

에너지 하베스터의 모든 유형은 특정 작동 메커니즘, 전기 회로 설계, 그리고 출력 성능 등을 지닌다. 역학 적-태양 에너지, 열에너지-태양에너지, 그리고 서로 다 른 유형의 역학적 에너지와 다양한 에너지 원천을 이용 하는 에너지 하베스터들의 하이브리드화를 위해서는 특 정 매개변수들이 고려되어야 한다. 하이브리드 에너지 하베스터의 최근 발전은 표 2에 나타나 있다. 표 2 는 수 확되는 에너지 종류들과 출력 성능을 보여준다. 태양광 전지와 열전 에너지 하베스터는 직류 형태의 전기적 출 력을 발생시키며, 압전 또는 마찰전기 에너지 하베스터 등은 교류 형태의 전기적 출력을 산출할 수 있다. 그러
나 일반적으로 전자기기를 작동하기 위해서는 직류 신 호가 필요하므로, 해당 에너지 하베스터들은 교류 신호 를 직류 신호로 변경시키는 정류기와 같은 부가적 장치 들이 필요하다.

많은 전략들이 보고되었지만, 자가 발전의 전자기기 를 위한 에너지 하베스터 이용을 가로막는 다양한 문제 들이 지적되어 왔다. 첫째로, 에너지 하베스터의 소자 구조는 진동 운동에 장기간 노출되면 내부 물질구조의 변형으로 인해 오히려 출력 성능을 약화시킬 수 있다. 둘째로, 출력 전력은 너무 낮기에 연속적으로 전자 제품 을 작동시키기 어렵다. 표 2에 나타나듯이, 다양한 하이 브리드 에너지 하베스터에서는 단일 에너지 수확 메커 니즘보다 출력 성능이 증가하였지만 대부분은 출력 전 압이 $30 \mathrm{~V}$ 도 넘기기 힘들다는 것을 알 수 있다. 즉, 에 너지 하베스터들의 하이브리드화에도 출력 성능은 여전 히 충분치 않다는 문제가 있는 것이다. 이밖에도 복합체 합성 과정 또한 중요한 요소로 간과될 수 없다. 복합체 합성은 저렴하고 효율적인 방식에서 소자를 제작하기 


\section{특 집 ㅁ Aamir Rasheed, 박현제, 손민균, 이태형, 강대준}

위해 이용 물질의 공정 과정은 용이하고 대면적 생산이 가능해야 한다. 특히, 에너지 하베스터의 다양한 응용을 위해 기계적 진동과 대면하는 복합체는 넓은 범위의 진 동수에서 효과적인 출력 성능을 산출할 수 있어야 한다.

복합체 기반의 하이브리드 에너지 하베스터의 개발 및 설계에 있어 출력 성능 향상을 위해서는 임피던스 일 치, 소자 설계, 작동 진동수, 그리고 부가 저항 등이 고 려될 필요가 있다. ${ }^{115-120)}$ 기계적 내구도와 전기적 임피던 스 일치는 출력 전력을 최대화시키기 위해 반드시 다뤄 져야 할 중요한 요소이다. 예를 들어, 구부림, 진동, 그 리고 온도 변화 등의 해당 에너지 원천에 오랜 기간 노 출된 이후에도 에너지 하베스터는 재현성 있고 믿을 만 한 출력 성능을 유지해야만 하고, 습하거나 온도 변화에 의해 소자의 출력 성능이 변해서는 안 된다. 그리고 에 너지 하베스터는 슈퍼커패시터나 일반 배터리 등에 저 장가능한 방식에서 고출력 전력을 생산할 필요가 있으 며, 센서, 나노 크기의 소자, 또는 심지어 일반 전구와 같은 응용에 직접적으로 이용될 수 있어야 한다. 넓은 범위의 작동 진동수 역시 중요한 요소이다. 왜냐하면 대 부분의 주변 움직임과 신체 활동은 $10 \mathrm{~Hz}$ 미만의 진동 수를 가지나 어떤 자연적 진동은 50-60 Hz의 보다 높

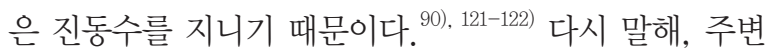
움직임은 임의적인 진동수를 갖는다. 따라서, 다양한 역 학적 에너지를 수확하는 소자를 제작하기 위해서는 상 대적으로 넓은 범위의 작동 진동수를 가지는 것이 출력 성능이나 소자의 응용가능성에 유리하다. 마지막으로, 소자의 상업적 용도를 고려하여 소자 제작과정의 용이 성과 비용의 문제 또한 간과될 수 없는 문제이다.

\section{2. 압전-마찰전기 하이브리드 에너지 하베스터}

현재, 하이브리드 에너지 하베스터는 압전, 마찰전기, 그리고 열전(pyroelectric) 효과 등을 소자내에 동시적 으로 구현하여 출력 성능을 효과적으로 개선하기 위해 많은 기술적 관심을 가지고 있다. 66 ), 98), 100), 123-125) 단일 압 전 에너지 하베스터에서 외부 힘에 노출된 압전기 발전 층은 보통 구부러지거나 압착되어 전기적 분극화가 발 생한 이후 다시 원상태로 돌아온다. 이러한 가역적 과
정에서 기판과 전극 사이의 마찰로 인해 발생한 에너지 는 쉽게 버려지거나 소자 설계에서 간과되는데, 이 낭비 되는 에너지는 마찰대전을 유도하는 물질과 압전 물질 의 합성과 이용을 통해 마찰대전과 압전기 발생 두 가지 의 에너지 수확 메커니즘을 단일 소자 내부에 구현할 수

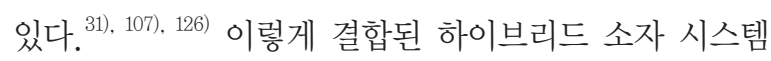
에서 마찰전기 에너지 하베스터와 압전 에너지 하베스 터의 장점들(즉, 고출력 전압과 전류)은 반복적인 외부 힘에서 가역적이고 지속가능한 방식이 동시적으로 구현 된다. 따라서, 결과적으로 이러한 하이브리드 소자는 보 다 높은 출력의 전력을 생산할 수 있는 것이다. ${ }^{28)}$ 두 방 식의 에너지 하베스터들은 보통 비슷한 수준의 임피던 스 일치와 작동 진동수를 지니기에, 두 메커니즘은 고출 력 하이브리드 소자를 얻기 위해 결합될 수 있다. ${ }^{22)}$ 두 에너지 하베스터들의 결합과 작동에 대해서는 Haixia Zhang 교수 연구팀에 의해 작동 원리, 외부힘 의존성, 그리고 전하교환 효율과 같은 에너지 하베스터의 특성 들을 분명하게 분석하는 컴퓨터 시뮬레이션 연구가 수 행되었다. ${ }^{127)}$ 특히, 이들은 압전 효과와 마찰전기 효과 를 동시에 발생시키는 압전-마찰전기 복합체가 하이브 리드 소자의 특정적인 구조 설계와 분극화 방향 의존성 이 함께 결합하여 효과적으로 출력 성능을 개선시킨다 는 것을 시뮬레이션 분석과 실험 결과를 통해서 증명하 였다.

\section{3. 압전-마찰전기 하이브리드 에너지 하베스터의 3 가지 작동 방식}

현재까지 다양한 형태의 하이브리드 에너지 수확 메 커니즘이 있으나, 특히 압전-마찰전기 복합체를 이용한 하이브리드 에너지 하베스터의 작동 방식에 대한 상당 한 연구가 있어왔다. 현재까지의 연구들을 종합해보면 그림 4에서 제시하는 것처럼 압전-마찰전기 하이브리 드 에너지 하베스터에는 3 가지의 근본적인 작동 방식들 이 있다.

1. 압전 효과에 의한 출력 성능은 복합체에서 압전 효 과를 담당하는 부분과 마찰전기를 유도하는 부분 사이에 하나의 전극을 공유하는 것으로 증대될 수 
(a)

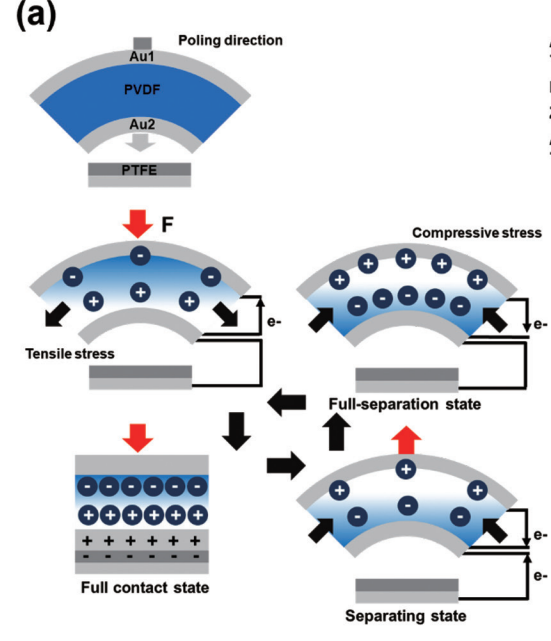

(b)

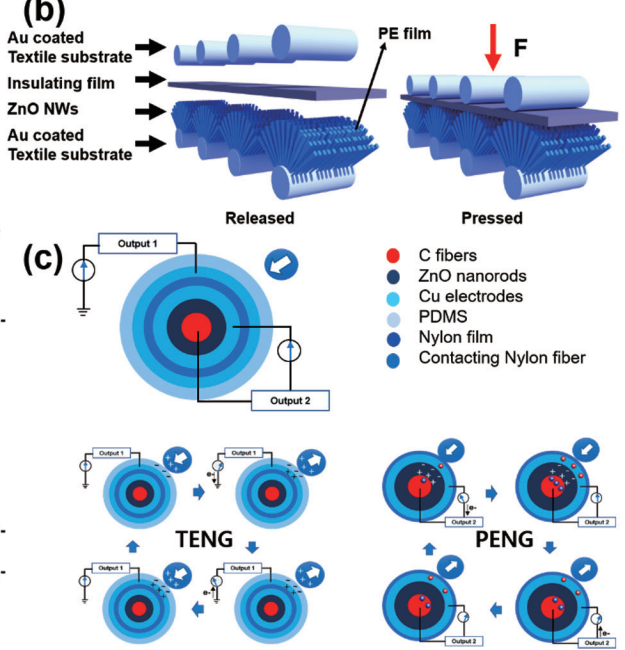

그림 4. 압전-마찰전기 하이브리드 에너지 하베스터의 작동 방식들. (a) 하이브리드 에너지 하베스터 내부에서 압전기 발생에 대한 메커니 즘. ${ }^{28)}$ (b) 압전-마찰전기 에너지 하베스터의 차폐 모드(screen mode) 제거에 대한 계략도 ${ }^{13)}$ (c) 압착-분리 주기에서 압전-마찰전 기 에너지 하베스터의 세 번째 모드의 계략도. ${ }^{139}$

있다. 마찰전기 효과로 인해 형성된 전하는 쉽게 압 전 전극과 결합할 수 있으며, 이에 압전기는 효과적 으로 발생할 수 있다. ${ }^{100), 123), ~ 128-132) ~}$

2. 복합체의 마찰전기 접촉면에서 정전기 전하는 두 압전층 사이의 전위차를 증가시킬 수 있다. 이 결 합 방식에서 압전기 발전층의 한 면에서 유도되는 마찰전하는 다른 면에 대한 전위차를 증가시킨다. 결과적으로 한 면에서 증가한 전위차는 더 많은 전 자들의 교환을 허용한다. ${ }^{15,}{ }^{33), 133-138)}$

3. 단일 압착-분리 주기 동안 두 유형의 에너지 하베 스터(마찰전기 에너지 하베스터와 압전 에너지 하 베스터)는 압전-마찰전기 복합체 내부에서 각각 독 립적으로 전기적 출력 신호를 발생시키는데, 결과 적으로 전체 출력 성능을 증가시킨다. ${ }^{124-125), ~}{ }^{139-141)}$ 합리적인 소자 설계는 전체 출력 성능을 효과적으 로 증가시킬 수 있는데, 정류기, 부가저항, 또는 전 극과 압전물질의 구성 등이 적절한 방식에서 선택 되고 제어되어야 한다.

표 3 은 작동 방식에 따라 서로 다른 출력 성능을 보 여준다. 여기에 따르면 하이브리드 소자의 작동 방식 은 대부분 마찰전기 에너지 하베스터의 접촉-분리 방식
이나 단일 전극 방식을 따른다는 것을 알 수 있는데, 기 계적 압착에 의한 압전 효과와 마찰대전 현상을 동시적 으로 구현하기에 최적의 소자 구조이기 때문이다. 따라 서 우수한 출력 성능의 하이브리드 소자를 제작하기 위 해서는 두 에너지 수확 메커니즘이 동시적으로 구현되 는 방식으로 소자 설계를 고려해야만 한다는 것을 알 수 있다.

\section{4. 하이브리드 에너지 하베스터의 최근 기술 동향 및 문제}

2015년 별도의 나노구조를 이용하지 않고도 작은 기 계적 힘에 의해 매우 높은 출력 전력을 산출하는 하이 브리드 에너지 하베스터 개발이 보고되었다. ${ }^{28)}$ 해당 연 구진은 소자상 에너지 하베스터와 마찰전기 에너지 하 베스터를 통합하여 압전 효과와 마찰대전을 동시적으 로 발생시켜 고출력 성능 달성에 기여할 수 있음을 증 명하였다. 이러한 하이브리드 소자에서는 $370 \mathrm{~V}$ 의 출 력 전압, $\sim 12 \mu \mathrm{Acm}^{-2}$ 의 출력 전류밀도, 그리고 4.44 $\mathrm{mWcm}^{-2}$ 의 평균 전력 밀도가 측정되었고, $0.2 \mathrm{~N}$ 의 작 은 힘에서도 600 개의 LED 등이 점등되었다. 그러나, 우 수한 출력 성능에도 불구하고, 이 연구에서 제안된 소자 


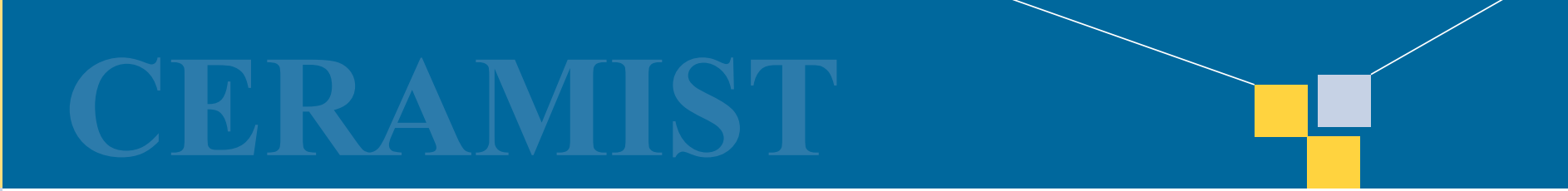

\section{특 집 ㅁㅁ Aamir Rasheed, 박현제, 손민균, 이태형, 강대준}

표 3. 압전-마찰전기 하이브리드 에너지 하베스터의 다양한 방식들의 성능 요약.

\begin{tabular}{|c|c|c|}
\hline 보고 연도 & 작동 방식 & 출력 성능 \\
\hline $2012^{133)}$ & 측면 슬라이딩 방식 & $8 \mathrm{~V}, 2.5 \mu \mathrm{A}$ \\
\hline $2013^{31)}$ & 접촉-분리 방식 & $\begin{array}{l}\text { 압전 에너지 하베스터: } 52.8 \mathrm{~V}, 20.75 \mu \mathrm{Acm}^{-2}, 10.95 \mathrm{mWcm}^{-3} \\
\text { 마찰전기 에너지 하베스터: } 240 \mathrm{~V}, 3.40 \mu \mathrm{Acm}^{-2}, 2.04 \mathrm{mWcm}^{-3}\end{array}$ \\
\hline $2013^{100)}$ & 접촉 분리 방식 & $20 \mathrm{~V}$ \\
\hline $2014{ }^{139)}$ & 단독 마찰대전 방식 & $\begin{array}{l}\text { 압전 에너지 하베스터: } 42.6 \mathrm{mWm}^{-2} \\
\text { 마찰전기 에너지 하베스터: } 10.2 \mathrm{mWm}^{-2}\end{array}$ \\
\hline $2014^{134)}$ & 단일 전극 방식 & $22 \mathrm{~V}, 9 \mu \mathrm{A}, 1.13 \mu \mathrm{Acm}^{-2}$ \\
\hline $2014^{137)}$ & 단일 전극 방식 & $215 \mathrm{~V}, 7.55 \mu \mathrm{Acm}^{-2}$ \\
\hline $2015^{142)}$ & 접촉-분리 방식 & $\begin{array}{l}\text { 압전 에너지 하베스터: } 6 \mathrm{~V} \\
\text { 마찰전기 에너지 하베스터: } 30 \mathrm{~V}\end{array}$ \\
\hline $2015^{124)}$ & 단일 전극 방식 & $\begin{array}{l}\text { 압전 에너지 하베스터: } 5 \mathrm{~V}, 98.66 \mu \mathrm{W}, 1.98 \mathrm{mWcm}^{-3} \\
\text { 마찰전기 에너지 하베스터: } 30 \mathrm{~V}, 9.74 \mu \mathrm{W}, 0.689 \mathrm{mWcm}^{-3}\end{array}$ \\
\hline $2015^{28)}$ & 접촉-분리 방식 & $370 \mathrm{~V}, 12 \mu \mathrm{Acm}^{-2}, 4.44 \mu \mathrm{Wcm}^{-2}$ \\
\hline $2015^{136)}$ & 단일 전극 방식 & $210 \mathrm{~V}, 2.1 \mu \mathrm{W}, 45 \mu \mathrm{A}$ \\
\hline $2015^{135)}$ & 단독 마찰대전 방식 & $38.4 \mathrm{~V}, 3.2 \mu \mathrm{Acm}^{-2}$ \\
\hline $2016^{33)}$ & 단독 마찰대전 방식 & $3.3 \mathrm{~V}$ \\
\hline $2016^{24)}$ & 접촉-분리 방식 & $\begin{array}{l}\text { 압전 에너지 하베스터: } 25 \mathrm{~V}, 98.56 \mu \mathrm{W}, 1.98 \mathrm{mWcm}^{-3} \\
\text { 마찰전기 에너지 하베스터: } 2.5 \mathrm{~V}, 9.74 \mu \mathrm{W}, 0.689 \mathrm{mWcm}^{-3}\end{array}$ \\
\hline $2016^{15)}$ & 단독 마찰대전 방식 & $40 \mathrm{~V}, 0.28 \mu \mathrm{A}, 70 \mathrm{mWm}^{-2}$ \\
\hline $2016^{32)}$ & 접촉-분리 방식 & $\begin{array}{l}\text { 압전 에너지 하베스터: } 47.8 \sim 96 \mathrm{~V} \\
\text { 마찰전기 에너지 하베스터: } 345.4 \sim 361.27 \mathrm{~V}\end{array}$ \\
\hline $2017^{143)}$ & 단일 전극 방식 & $280 \mathrm{~V}, 25 \mu \mathrm{A}$ \\
\hline $2017^{123)}$ & 접촉-분리 방식 & $190 \mathrm{~V}, 16.46 \mu \mathrm{W}$ \\
\hline $2017^{144)}$ & 단일 전극 방식 & $300 \mathrm{~V}, 16 \mathrm{mAcm}^{-2}$ \\
\hline $2018^{98)}$ & 접촉-분리 방식 & (개회로 출력 전압) $572 \mathrm{~V}, 1336 \mathrm{Wm}^{-2}$ \\
\hline $2018^{145)}$ & 접촉-분리 방식 & $60 \mathrm{~V}, 2.0 \mu \mathrm{A}, 50 \mu \mathrm{Wcm}^{-2}$ \\
\hline $2019^{140)}$ & 단일 전극 방식 & $210 \mathrm{~V}, 395 \mu \mathrm{A}, 10.88 \mu \mathrm{W}$ \\
\hline $2019^{131)}$ & 접촉-분리 방식 & $2.7 \mathrm{kV}$ \\
\hline $2019^{129)}$ & 접촉-분리 방식 & $42 \mathrm{~V}, 1.7 \mathrm{mAm}^{-2}, 161.7 \mathrm{mWm}^{-2}$ \\
\hline $2019^{132)}$ & 접촉-분리 방식 & $90 \mathrm{~V}, 11 \mu \mathrm{A}$ \\
\hline $2019^{141)}$ & 단일 전극 방식 & $130 \mathrm{~V},(2 \mathrm{~Hz}$ 진동수에서 $) 4 \mu \mathrm{A}, 8.34 \mathrm{mWm}^{-2}$ \\
\hline $2019^{130)}$ & 접촉-분리 방식 & $18 \mathrm{~V}, 1.6 \mu \mathrm{Acm}^{-2}$ \\
\hline
\end{tabular}

는 두 유형의 에너지 하베스터들이 분리되어 있기 때문 에 진정한 의미에서 하이브리드 소자라 하기 어렵다는 한계를 지닌다.

2015년 Chunsheng Yang 교수 연구팀은 유연 소재 기반의 통합형 압전-마찰전기 에너지 하베스터를 개발 하였다. ${ }^{142)}$ 이들은 압전-마찰전기 에너지 하베스터를 제 작하기 위해 PDMS-MWCNT 나노복합체를 마찰전기 물질로 이용하였다. 그리고 여기에 알루미늄 시트로 뒤 덮인 $\mathrm{PVDF}$ 박막은 마찰전기 복합체에 코팅되어 소자
내부에서 압전 물질로서 이용되었고, 알루미늄의 양 전 극은 각각 $\mathrm{PDMS}$ 와 $\mathrm{PVDF}$ 에 부착되었다. 소자 설계에 있어서 소자의 윗부분은 압전효과를, 아랫부분은 마찰 전기 효과를 이용하도록 설계되었다. 가볍게 두드리는 힘이 $\mathrm{PDMS}-\mathrm{MWCNT}$ 마찰전기 복합체에 가해질 때, 이 마찰전기 층이 접촉하여 양 쪽에 전하를 유도해 전위 차를 야기함과 동시에 PVDF에서 압전 효과 또한 발생 하여 두 메커니즘에서 출력 성능이 발생하였다. 그림 $5 \mathrm{a}$ 과 $\mathrm{c}$ 는 해당 소자의 구성과 작동 원리를 보여준다. 이들 
(a)

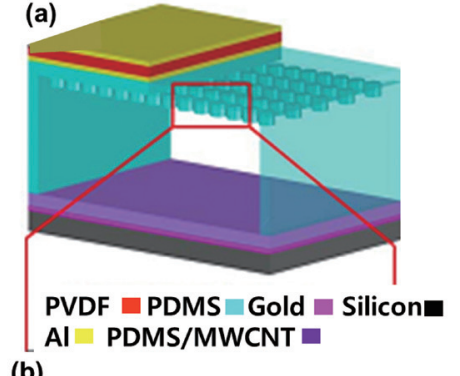

(b)

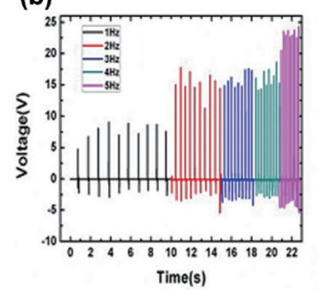

(c)

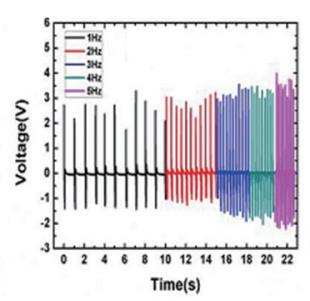

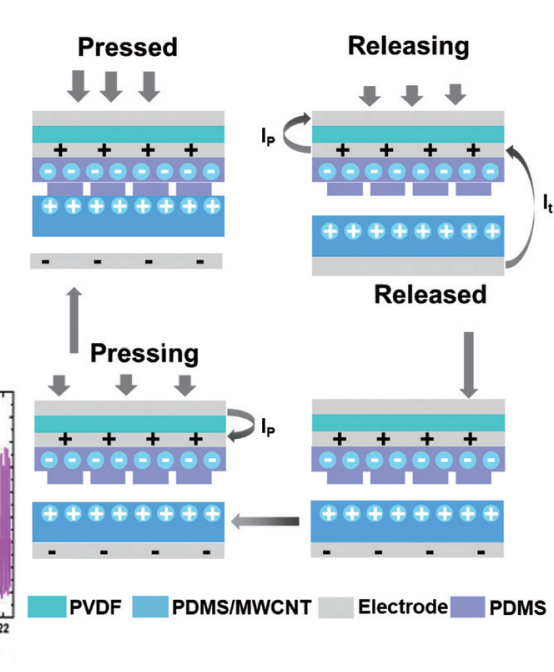

그림 5. (a) 압전-마찰전기 하이브리드 에너지 하베스터 도식도. (b) $1 \sim 5 \mathrm{~Hz}$ 의 진동수 범위에서 마찰전기(좌) 와 압전기(우) 출력 성능 (c) 소 자의 작동 원리. 압전-마찰전기 에너지 하베스터의 차폐 모드(screen mode) 제거에 대한 계략도. ${ }^{142)}$

의 관측 결과는 그림 $5 \mathrm{~b}$ 에 나와 있는 것처럼, 압전 에너 지 하베스터와 마찰전기 에너지 하베스터의 출력 전압 은 $5 \mathrm{~N}$ 의 $5 \mathrm{~Hz}$ 진동수에서 $6 \mathrm{~V}$ 와 $20 \mathrm{~V}$ 로 각각 관측되 었다. 또한 출력 전력은 $15 \mathrm{M} \Omega$ 과 $1 \mathrm{M} \Omega$ 의 저항에서 각 각 $3.4 \mu \mathrm{W}$ 와 $\sim 0.12 \mu \mathrm{W}$ 의 값을 보였다. ${ }^{142)}$

2016년 Zhong Lin Wang 교수 연구팀에서는 다층 나노복합체 기반의 하이브리드 에너지 하베스터를 보고 하였다. ${ }^{143)}$ 이들이 제작한 소자는 단일 소자 구조 내에 서 오직 2 개의 전극만을 이용하는데, 이때 두 가지의 서 로 다른 에너지 수확 메커니즘이 이용됨에 따라 상호간 에 시너지 효과까지 보인다는 것이 증명되었다. 이들의 소자에서 압전 에너지 하베스터의 전극으로서 MWCNT 와 $\mathrm{PDMS}-\mathrm{BTO}$ 복합체가 이용되었다. MWCNT는 전극 에 전기 전도성을 제공해주었고 $\mathrm{PDMS}-\mathrm{BTO}$ 나노복합 체는 마찰전기 효과와 압전 효과를 동시에 구현하는 물 질로 이용되었다. 마찰전기를 발생시키는 부분에 있어, 접촉층은 $\mathrm{PTFE}$ 나노입자들이 $\mathrm{PDMS}$ 에 삽입되어 제작 되었다. 하이브리드 메커니즘에 있어 PDMS-BTO 나노 복합체에서 분극화가 발생하는데, 이때 분극된 BTP 나 노플레이트는 표면층을 따라 정렬되어 전극에 전하들을 위치시켰다. 외부 힘이 PDMS에 인가되면서 PDMS$\mathrm{BTO}$ 층의 두께는 감소하고, 결국 쌍극자 모멘트와 전
극의 전하밀도가 감소하여 전류를 발생시켰다. 또한, 다 른 면과 접촉하는 동안에 전자들은 양 전극 사이의 전위 차로 인해 흘러갔다. 이들의 측정에 따르면 $2.5 \mathrm{~cm} \times$ $2.5 \mathrm{~cm}$ 크기의 단일소자에서 그림 6 에서 보여지는 것 처럼 $280 \mathrm{~V}$ 의 개회로 전압과 $25 \mu \mathrm{A}$ 의 단락전류가 측정 되었다.

2015년 Junyang Li 교수 연구팀은 고출력 성능을 달 성하는 하이브리드 소자를 개발하였는데, 소자 구성에 있어 더 높은 출력신호를 산출하기 위해 PDMS 표면 위 에 BTO 나노입자와 MWCNT를 합성한 복합체 기반의 아치 형태(arch-shaped) 소자를 제작하였다. ${ }^{134)}$ 이 하 이브리드 마찰-압전 메커니즘은 doctor blade 방식을 통해 밝혀졌다. 이용된 복합체에서 MWCNT는 BTO 나 노입자의 서로 간의 엉겨 붙음을 방지하는 동시에 복합 체의 전도도를 향상시켰다. 복합체 매트릭스는 PET/ $\mathrm{ITO}$ 와 알루미늄 호일 전극 사이에 삽입되었다. 그림 $7 \mathrm{a}$ 는 소자의 작동 메커니즘을 보여준다. 출력 성능은 15 에 서 $25 \mathrm{~Hz}$ 사이에서 분석되었고, 전압의 증가는 5 에서 $22 \mathrm{~V}$ 이었다. 이 소자는 그림 $7 \mathrm{~b}$ 에서 보여지는 것처럼 $25 \mathrm{~Hz}$ 이상의 진동수에서는 낮은 성능을 보였다. 이는 여러 응용을 고려할 때, 충분치 않은 진동수로 하이브리 드 에너지 하베스터 소자 설계에 있어서 진동수 최적화 


\section{특 집 ㅍ Aamir Rasheed, 박현제, 손민균, 이태형, 강대준}

(a)

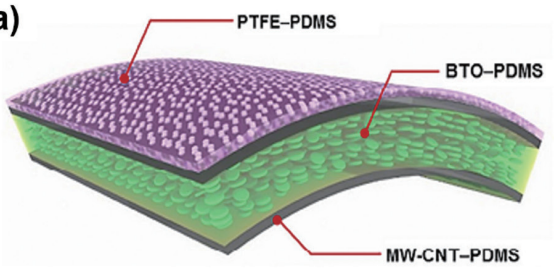

(c)

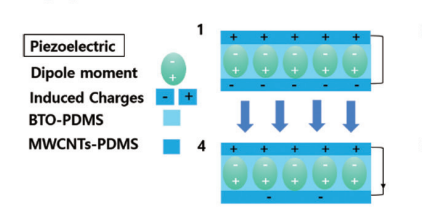

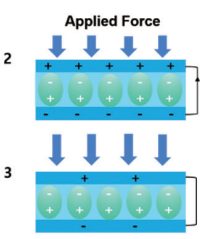

(b)
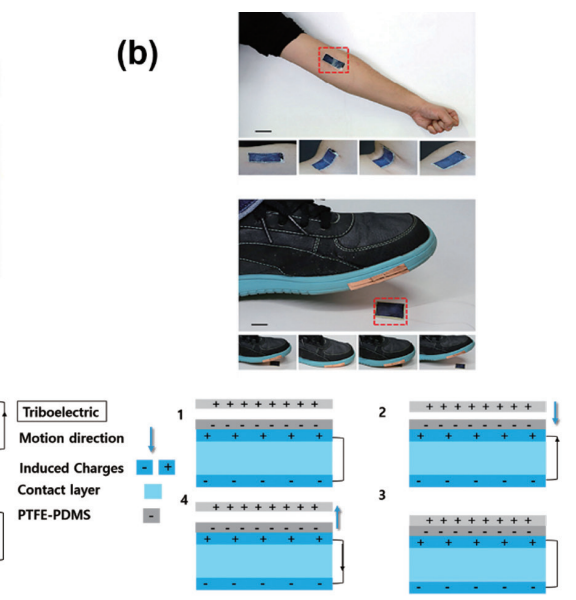

그림 6. (a) 하이브리드 에너지 하베스터의 개략도. (b) 구부러짐 주기에서 출력 전류의 증가 도식도. 착용된 하이브리드 에너지 하베스터는 에너지를 수확하는데 이용된다. 삽입 이미지는 한 주기에서 움직임을 보여준다. (c) 압전, 마찰전기, 그리고 압전-마찰전기 하이브리 드 에너지 하베스터의 작동 원리. ${ }^{143)}$

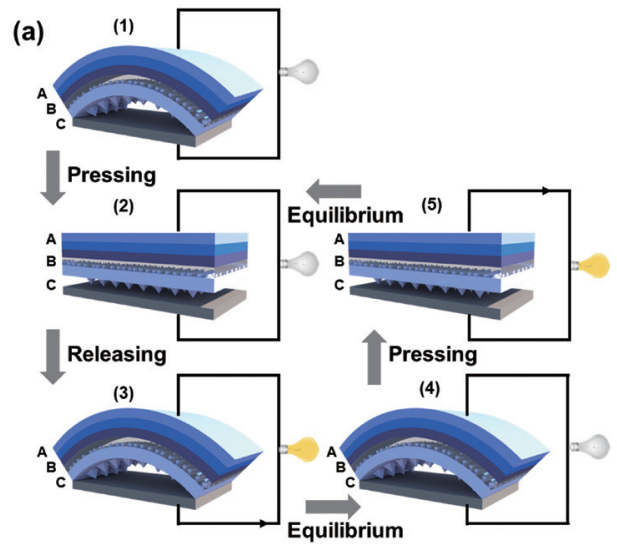

(b)

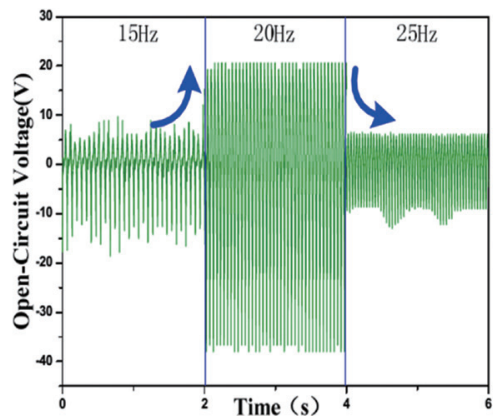

그림 7. (a) 아치 형태의 압전-마찰전기 하이브리드 에너지 하베스터의 작동 원리. (b) $15 \sim 25 \mathrm{~Hz}$ 사이에서 측정된 소자의 출력 성능. ${ }^{134)}$

를 고려해야만 한다는 점을 시사해준다.

2016년 Jianye Li 박사 연구팀에서는 ITO/PET 전극 위에 나노복합체를 이용하여 출력 에너지를 증가시키 는 하이브리드 소자를 개발하였다. ${ }^{33)}$ 그림 $8 \mathrm{a}$ 에 나타나 는 것처럼, 이들의 하이브리드 에너지 하베스터는 용이 하게 제작가능한 방식에서 $\mathrm{BaTiO}_{3}$ 나노입자들이 PDMS 필름에 삽입된 복합체를 이용하였다 (그림 $8 \mathrm{a}$ ). 이들에 따르면 PDMS 내부에 위치한 이 BTO 입자들의 비율은 압전 분극화 방향과 마찰대전에 밀접한 관련을 보였는 데 결과적으로 $20 \mathrm{wt} \%$ 에서 가장 큰 출력 성능을 내보 였다. 그림 $8 \mathrm{~b}-\mathrm{d}$ 은 측정된 이들 소자의 출력성능을 보 여주고 있다. 세 가지의 방식들, 즉 마찰전기 에너지 하
베스터, 압전 에너지 하베스터, 그리고 압전-마찰전기 에너지 하베스터가 각각 측정에 이용되었으며, $2.2 \mu$ $\mathrm{F}$ 의 축전기가 부착된 모든 방식에서 산출될 신호의 저 장 효율은 그림 8d에 나타나 있다. 소자의 출력 전압은 forward poling 메커니즘에서 최대 $12 \mathrm{~V}$ 로 상당히 낮았 으며, $\sim 0.015 \mathrm{Cm}^{-2}$ 의 낮은 분극화는 장기간에 걸쳐 유 지되지 못한다는 한계를 내보인다.

2017년 Haixia Zhang 교수 연구팀은 파도 형태 의 하이브리드 소자를 개발하여 압전 효과와 마찰 전기의 시너지 효과를 이용하고자 하였다. ${ }^{32)}$ 유연한 Polyvinylidene fluoride trifluoroethylene (P(VDF$\mathrm{TrFE})$ ) 나노섬유의 합성을 통해 압전 효과가 구현되었 


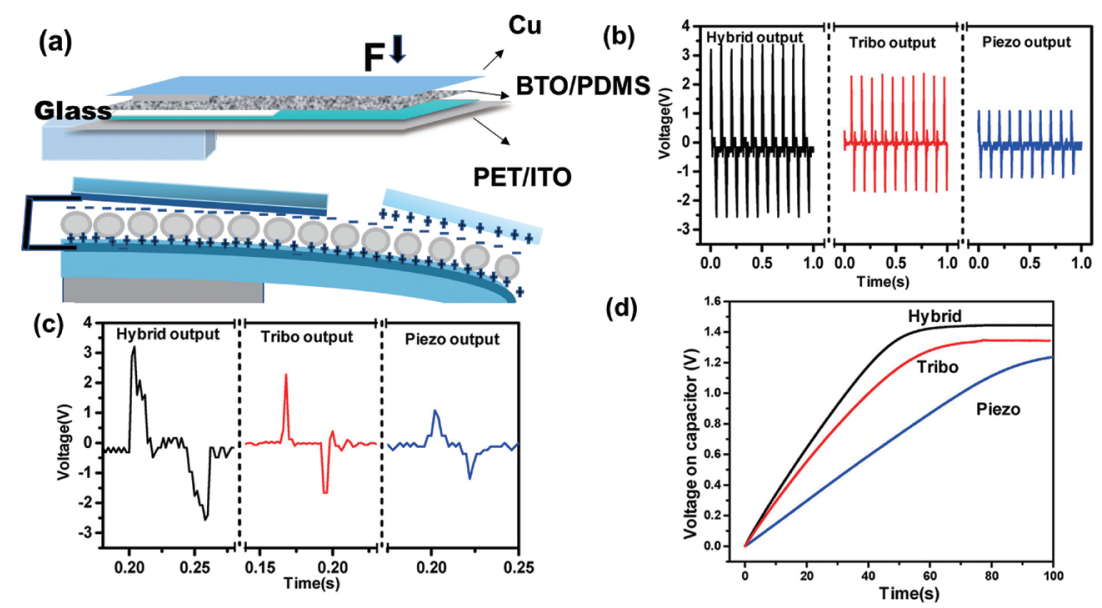

그림 8. (a) 각각의 효과에 대한 기요도 연구와 개략적인 설계. (b) 각각 모드에서 출력 전압. (c) 세 모드에서 단일 신호 결과 . (d) $2.2 \mu \mathrm{F}$ 충 전기에서 충전된 전하의 결과 ${ }^{33}$

(a)

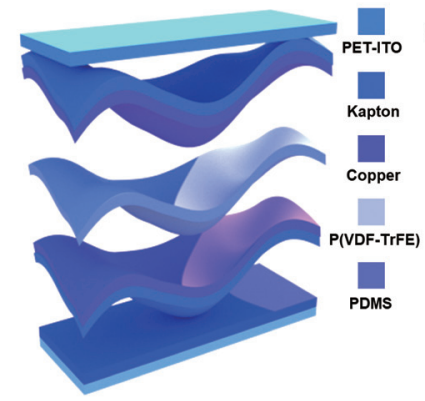

(b)

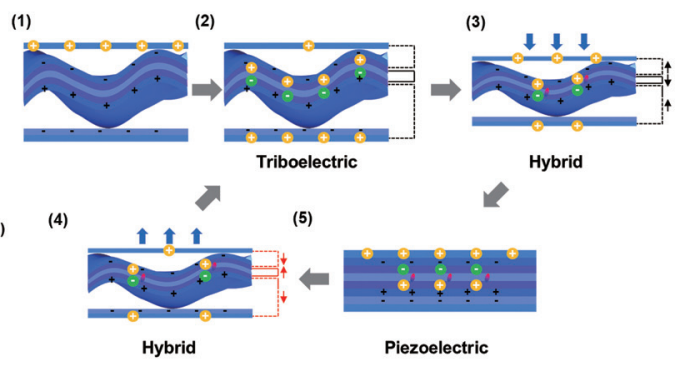

그림 9. (a) 하이브리드 소자의 구조적 도식도. (b) 하이브리드 소자의 작동 메커니즘. (1) 접촉-분리의 수 사이클 이후에 마찰전기 층에서 형 성된 전하. (2) 분리 단계. 전하들은 마찰전기 전하의 정전기적 유도 하에 동등하게 분포된다. (3) 접촉 단계. 압전 전위과 마찰전기 전하는 외부 회로를 따라 마찰 전하들이 전하들이 위로 움직이게 한다. (4) 재분리 단계. 전하들은 압전 전위차에 의해 유도된 평형 상태에 도달한다. (5) 그리고, 압전 전위차가 줄어들면서 전하들은 반대로 움직인다. ${ }^{32)}$

고, 복합체와 부착된 캡톤 필름이 마찰전기 층으로 이 용되었다. 압전 에너지 하베스터는 두 마찰전기 에너 지 하베스터 사이에 삽입되었고, 파도 형태의 구조는 형 성된 공간을 통해 소자의 자기회복적 특성을 내보였다. $\mathrm{P}(\mathrm{VDF}-\mathrm{TrFE})$ 나노섬유는 전기방사(electrospinning) 기법을 통해 베타 상(beta phase)을 가지도록 합성되었 다. 소자 제작에 있어, 유리 전극은 캡톤 필름을 통해 파 도 형태를 유지하도록 부착되었으며, 2 시간동안 $200{ }^{\circ} \mathrm{C}$ 에서 열처리되었다. $200 \mathrm{~nm}$ 두께의 구리는 전극으로 이용되도록 캡톤 표면에 증착 되었고, 합성된 $\mathrm{P}(\mathrm{VDF}-$ $\mathrm{TrFE}$ ) 나노섬유는 두 캡톤 필름 사이에 삽입되었다. 이 구조에서 $\mathrm{PET}-\mathrm{ITO}$ 는 전극뿐만 아니라 마찰층으로도
이용되어 소자의 단순성을 성취하고자 하였다. 마찰전 기 에너지 하베스터의 아래부분에서는 그림 $9 \mathrm{a}$ 에 보여 지는 것처럼 $\mathrm{PDMS}$ 가 PET-ITO 표면에 코팅되었다. 그 림 $9 \mathrm{~b}$ 는 제작된 소자의 작동 원리를 표현한다. 초기에, 구리와 PET-ITO 전극에는 어떠한 전하 분포가 있지 않 으나, 접촉-분리의 몇 사이클 이후에 마찰전기 층은 전 자 친화도에 의존하여 전기를 발생시킨다. (그림 $9 \mathrm{a}$ ). 이때, 캡톤 필름은 마찰전기 에너지 하베스터의 위아래 에 걸쳐 각각 음과 양의 마찰전기 층으로 작동하며, 전 하들은 각각 전기장을 최소화하기 위해 재분포된다 (그 림 $9 \mathrm{~b})$. 외부힘에 따라 양 마찰대전 층들이 서로 접촉 할 때, 전자들은 반대 방향으로 이동하기 시작한다. 동 
(a)

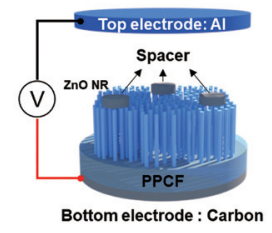

(d)

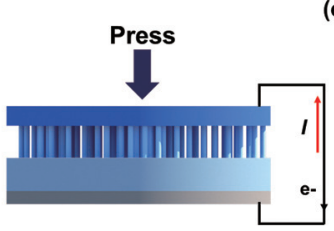

(b)

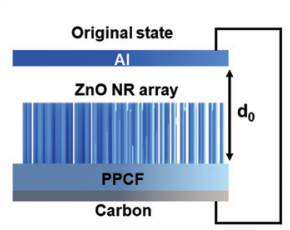

(e)

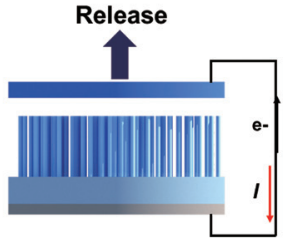

(c)

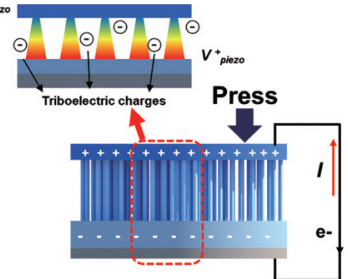

(f)

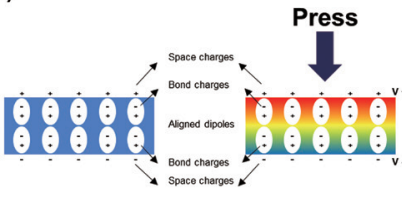

그림 10. (a) 압전-마찰전기 에너지 하베스터의 압전 효과와 마찰전기 발생의 개략도. (a) ZnO 나노막대기가 삽입된 하이브리드 소자. (b) d 가 $\mathrm{d}_{0}$ 와 동일할 때, 즉 기계적 압착 이전의 원래 상태. (c) 마찰전기 전하는 알루미늄이 $\mathrm{ZnO}$ 나노막대기가 접촉함에 따라 발생기 시 작한다. 외부 힘을 받는 $\mathrm{ZnO}$ 나노막대기는 음의 마찰전하를 접촉 단계 동안 발생시키며, 압전 포탠셜 또한 동시에 형성한다. (d) 기 계적 압착에서 PPCF, Al, 그리고 $\mathrm{ZnO}$ 나노막대기의 표면상 마찰전기 전하 분포. (e) 유도된 정전기 전하는 양의 마찰전기 전하를 상쇄한다. (f) 압착 전후로 전하의 배치 변화 ${ }^{15)}$

시에, 분극화는 $\mathrm{P}(\mathrm{VDF}-\mathrm{TrFE})$ 에서 형성되어 압전 효과 를 유도한다. 출력 성능에 있어 이러한 하이브리드 소자 는 위아래의 마찰전기 층에서 각각 80.27 88.33 V와 345.4 361.7 V가 측정되었고, 그 사이로 삽입된 압전 에너지 하베스터에서의 출력 전압은 47.8 96 V로 측정 되었다.

Walid Daoud 교수 연구팀은 마찰전기 물질로서 알 루미늄과 PDMS-PVDF 탄소 복합체로 구성된 하이브 리드 에너지 하베스터를 보고하였다. ${ }^{15)}$ 이들은 PDMS$\mathrm{PVDF}$ 복합체에다 $\mathrm{ZnO}$ 나노막대기를 수열 합성법 (hydrothermal growth method)으로 성장시켜 해당 복합체 표면 구성을 변화시켰다. 그림 10은 이들의 하 이브리드 소자가 작동하는 방식을 도시한다. 기계적 압 착이 소자에 가해지면서, 알루미늄이 PDMS-PVDF 층 에 가까워져 마찰전기가 발생하고, PDMS-PVDF 복합 체의 보다 큰 전자 친화도로 인해 전자가 흐르게 된다. 기계적 힘으로 인해 압착된 $\mathrm{ZnO}$ 나노막대기는 마찰전 기 층 위에서 음의 전하를 산출하였다. 동시에, $\mathrm{ZnO}$ 나 노막대기에서 분극화가 발생되었으나 복합체의 절연성 으로 인해 유도된 전하들이 이동하지 못하였다. 게다 가, $\mathrm{ZnO}$ 나노막대기의 비슷한 전자 친화도와 알루미늄 의 일함수로 인해 쇼트키 장벽이 형성되지 못하였다. 이 하이브리드 소자는 $40 \mathrm{~V}$ 의 개회로 전압과 $0.28 \mu \mathrm{A}$ 의
단락 전류, 그리고 $\sim 70 \mathrm{mWm}^{-2}$ 의 최대 전력밀도를 발 생시켰다. $10.5 \mathrm{M} \Omega$ 의 부가저항에서 최대 전환 효율은 $34.56 \%$ 이었다. 전체 출력 성능에서 마찰전기 효과는 압 전 효과에 비해 약 12.75 배 높았다. $\mathrm{ZnO}$ 나노막대기로 인한 전위차의 향상은 약 $21.8 \mathrm{~V}$ 이었다.

최근에, 전자기적, 압전, 마찰전기 효과를 이용하여 바람 에너지를 전기적 에너지로 변환시키는 하이브리드 에너지 하베스터가 광범위하게 연구되었으나, 기존 연 구에서는 대체적으로 구조적 설계가 크고 복잡한 공정 과정을 거쳐야만 한다는 문제가 지적되어 왔다. ${ }^{16), ~ 146-147) ~}$ 이러한 문제들을 극복하기 위해, Xiaoming Tao 교수 연구팀은 풍력 에너지를 수확하기 위한 단순한 하이브 리드 소자 설계를 발전시켰는데, 그림 11은 이 하이브리 드 소자를 간략하게 보여준다. ${ }^{123)}$ 효과적인 출력 성능을 위해 이들은 피라미드 형태의 PDMS 마이크로 구조체 를 이용하여 접촉면을 극대화시켰다. 그림 11c는 전자주 사현미경(scanning electron microscopy) 관측을 통해 이들 소자에 이용된 구조체들의 표면을 보여준다. 풍력 에 의한 두 마찰/압전 층의 접촉시, 이들의 측정에 따르 면 바람 속도가 $14 \mathrm{~m} / \mathrm{s}$ 에서 19.8 과 $17.4 \mathrm{~V}$ 가 관측되었 고, 상부 압전-마찰전기 층의 최대 출력 전력은 $10 \mathrm{~m} / \mathrm{s}$ 의 바람 속도에서 각각 $112 \mu \mathrm{W}$ 와 $76 \mu \mathrm{W}$ 이었다.

이총현 교수 연구팀은 $\mathrm{PDMS}$ 와 $\mathrm{ZnSO}_{3}$ 페로브스카이 
(a)

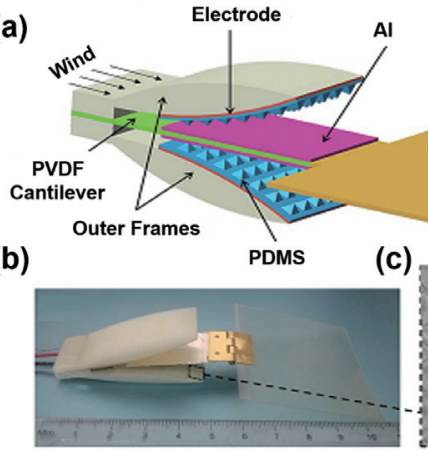

(c)

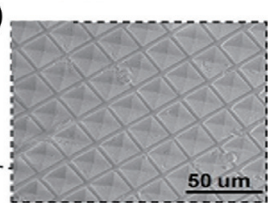

그림 11. (a) 바람개비 하이브리드 소자 개략도. (b) 제안된 하이브 리드 소자의 이미지. (c) 피라미드 구조로 제작된 PDMS 이미지 ${ }^{148)}$

트 나노큐브를 합성하여 압전-마찰전기 하이브리드 에 너지 하베스터를 제작하였다. ${ }^{144)}$ 이들이 제안한 소자 설 계는 압전 에너지 하베스터 부분과 마찰전기 에너지 하 베스터 부분이 수직적으로 서로 간에 쌓아 올려진 구조 로서, $\mathrm{PDMS}$ 와 페로브스카이트가 상보적인 마찰층을 공유하는 방식으로 마찰전기와 압전기를 각각 발생시 켰다. 납이 포함되어 있지 않은 $\mathrm{ZnSO}_{3}$ 는 복합체의 압 전 물질로 이용되었으며, $\mathrm{PDMS}$ 와의 합성을 통해 마찰 전기적 특성도 부여되었다. 또한, 자외선 노광을 통해 $\mathrm{PDMS}$ 의 표면 거칠기를 증가시켜 복합체 접촉면적의 증가를 가능하게 하였다. 외부 힘이 인가될 때, $\mathrm{PDMS}$ 는 음의 전하를 발생시켰고, 구리 전극은 접촉 이후에
양극으로 대전되었다. 상부전극에서 외부 힘의 증가는 $\mathrm{ZnSO}_{3}-\mathrm{PDMS}$ 복합체에서 분극화를 발생시켰다. 그림 $12 \mathrm{~b}$ 에서 보여지는 것처럼, 완전 접촉(full contact) 상태 에서 압전 성능과 마찰전기 성능 모두 전압 피크값이 각 각 $60 \mathrm{~V}$ 와 100 V로 관측되었다. 한편, 접촉한 면들 이 원상태로 돌아오는 단계에서, 그림 $12 \mathrm{a}$ 에 나타나는 것처럼 전자가 반대 방향으로 이동하면서 반대 방향의 전압 피크가 산출되었다. 소자의 전체적인 출력 성능 측 정에서 출력 전력, 전류밀도, 그리고 전압은 각각 10.41 $\mathrm{mWcm}^{-2}, 16 \mathrm{mAcm}^{-3}, 300 \mathrm{~V}$ 로 확인되었다.

하이브리드 소자 설계에 있어 최근에는 이중 아치형 으로 소자가 구성되어 압전기와 마찰전기를 발생시키는 메커니즘이 이러한 소자 구조를 따라 이중적으로 발생 하는 결과가 보고되었다. ${ }^{128)}$ 전극을 공유하는 형태에서 압전기와 마찰전기 부분들은 평행하게 연결되어 센서의 출력 특성과 민감도를 향상시켰는데, 이때 이 센서에서 $\mathrm{PVDF}$ 와 마이크로 패터닝이 실시된 실리콘 고무 복합체 가 압전 물질과 마찰전기 물질로 이용되었다. 그림 13은 소자의 작동 원리를 보여준다. $5 \mathrm{~N}$ 의 힘이 $10 \mathrm{~Hz}$ 에서 압전기 출력 전류와 전압은 각각 $42.6 \%$ 와 $25 \%$, 마찰전 기 출력 전류와 전압은 각각 $21.9 \%$ 와 $69.3 \%$ 증가하였 고, $3 \sim 6 \mathrm{~mm}$ 의 진동 진폭에서 $3.65 \sim 6.14 \mu \mathrm{W} / \mathrm{g}$ 의 민 감도(표준편차 4.23 5.11\%)가 확인되었다. 또한, $3.3 \mu$ $\mathrm{F}$ 의 축전기를 소자에 부착할 시 충전 후 약 9 초간 전자

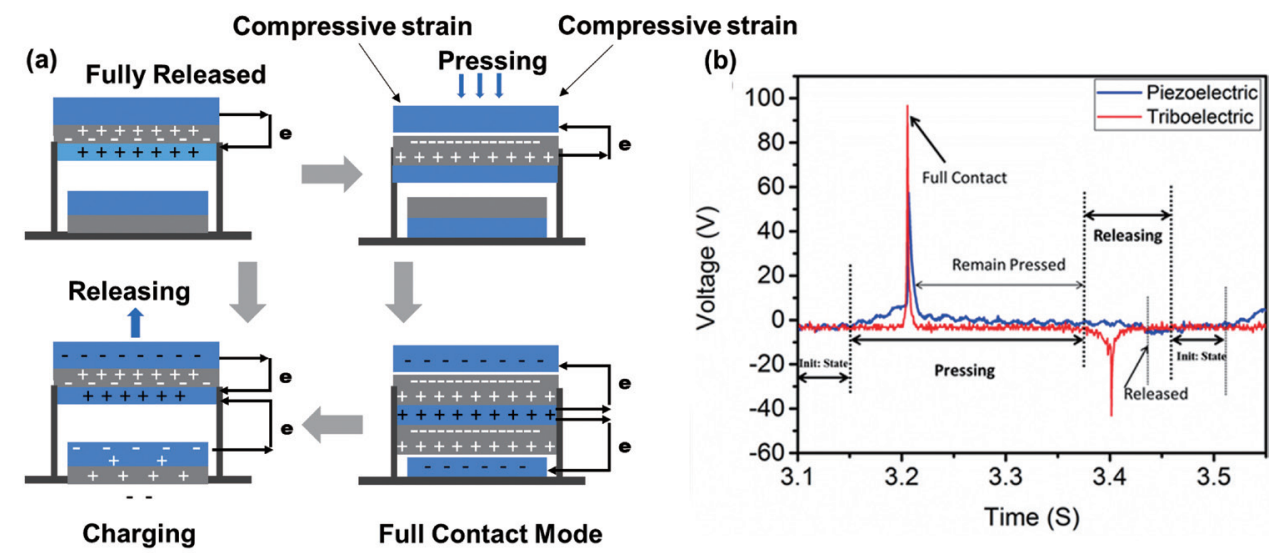

그림 12. (a) 제작된 하이브리드 소자의 작동 메커니즘. (b) 제작된 하이브리드 에너지 하베스터의 압전효과와 마찰전기 효과에서 동시적으 로 발생한 전압들 ${ }^{144}$ 


\section{특 집 ㅍ Aamir Rasheed, 박현제, 손민균, 이태형, 강대준}

(a)

(b)

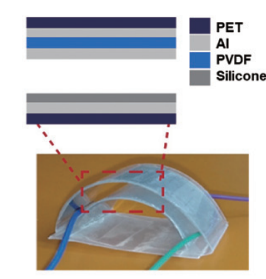

(1)

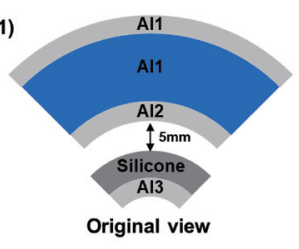

(5)

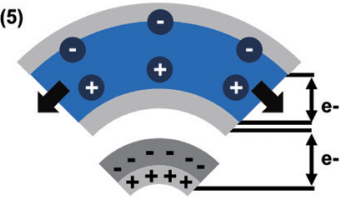

(2)

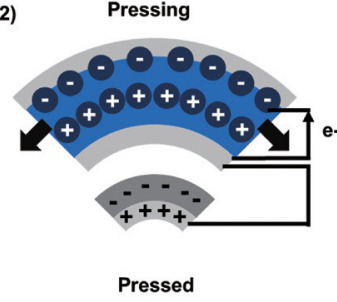

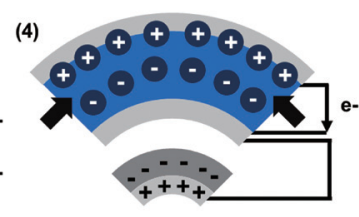

(3) Released

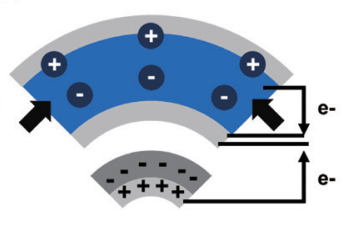

그림 13. (a) 이중 아치형 압전-마찰전기 하이브리드 소자의 개략도. (b) 하이브리드 에너지 하베스터의 작동 원리 ${ }^{128)}$.

미터를 작동시킬 수 있다. ${ }^{128)}$

지난 몇 년에 걸쳐 앞서 언급한 것처럼 에너지 하베스 터의 하이브리드 개념을 이용하여 해당 소자의 출력 전 력밀도를 개선시키는 시도를 하였다. 그러나, 소자 설 계에서 복잡성은 여전히 중대한 문제로 남아있다. 예 를 들어, 압전-마찰전기 에너지 하베스터의 통합 설계 에 관하여, 두 종류의 하베스터에서 발생하는 출력 신호 들을 통합하기 위해 정류기나 별도의 전극과 같은 추가 적인 요소들이 요구되는데 이는 소자 설계에서 복잡성 을 증가시킬 뿐만 아니라 출력 성능의 저하까지 초래한 다. 이러한 문제들을 극복하기 위해, 2018년 김상재 교 수 연구팀은 나비날개 구조의 하이브리드 소자를 설계 하였다. ${ }^{98)}$ 원호 형태의 단순한 하베스터 네 부분들은 서 로 독립적인 역할을 담당하였는데, 소자의 응용에 있어 서 네 아치형태의 하이드리드 에너지 하베스터는 압력 센서와 리튬이온 배터리 충전기 모두를 작동시키는데 이용되었다. 여기에 따르면, 높은 거칠기를 보이는 압전 물질 $0.3 \mathrm{Ba}_{0,7} \mathrm{Ca}_{0,3} \mathrm{TiO}_{3}-0.7 \mathrm{BaSn}_{0.12} \mathrm{Ti}_{0,88} \mathrm{O}_{3}$ 나노입자들 이 마찰전기 대전층 역할을 하는 $\mathrm{PDMS}$ 고분자 매트릭 스에 삽입되어 다기능성 복합 소재로 이용되었다. 출력 전압과 단락 전류는 $572 \mathrm{~V}$ 와 $1.752 \mathrm{~mA}$ 로 측정되었다. 또한, 세 가지의 구조적 특성(평면, 마이크로 원기둥, 아 치)에 따른 하이브리드 에너지 하베스터가 분석에 이용 되었는데, 아치 형태와 마이크로 원기둥 기반의 하이브 리드 에너지 하베스터가 평면 기반의 하이브리드 에너
지 하베스터에 비해 $\left(333 \mathrm{Wm}^{-2}\right)$ 각각 4 배와 2 배로 높은 전력 밀도 $\left(1336 \mathrm{Wm}^{-2}\right.$ 와 $\left.632 \mathrm{Wm}^{-2}\right)$ 를 보였다. 이 하 이브리드 에너지 하베스터의 복합체는 5 층 이하의 마찰 층을 지니며, 그림 14 에서 보여지는 것처럼 하이브리드 출력을 얻기 위해 추가적인 정류 장치를 필요로 하지 않 기 때문에 기존의 하이브리드 에너지 하베스터의 설계 보다 덜 복잡하다.

\section{5. 압전-마찰 하이브리드 에너지 하베스터에서 압전 효과 향상}

압전 에너지 하베스터와 마찰전기 에너지 하베스터의 조합을 이용하는 반도체 나노구조체 기반의 나노발전기 는 압전 차폐 효과의 감소를 통해 압전기를 증가시킬 수 있다. 마찰전기 효과는 각각의 층 사이의 마찰로 전하들 을 제공할 수 있다. 김현진 박사 연구팀은 $\mathrm{ZnO}$ 나노와 이어가 압전 물질로 이용되고 polyethylene $(\mathrm{PE})$ 가 마 찰전기 물질로 이용되는 하이브리드 에너지 하베스터를 보고하였다. ${ }^{133)}$ 압전 효과로 인해 $\mathrm{ZnO}$ 나노와이어 안의 전자들은 나노와이어에서 재분배된다. 그리고 $\mathrm{PE}$ 층과 나노와이어 접촉면 근처의 전자 밀도는 0 에 가까워지는 데, 이는 발생하는 압전기의 향상을 이끌어낸다.

Haixia Zhang 교수 연구팀은 PVDF와 PDMS를 합 성한 복합체 기반의 압전-마찰전기 하이브리드 에너 지 하베스터의 컴퓨터 시뮬레이션 분석을 통해 압전기 향상을 증명하였다. ${ }^{31} \mathrm{r}$-형태의 소자 구조는 압전기 발 
(a)

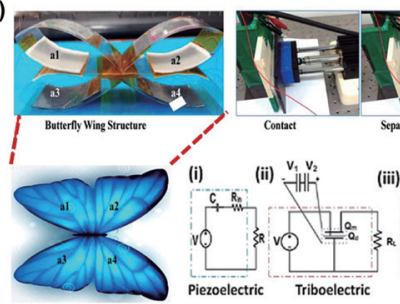

(c)

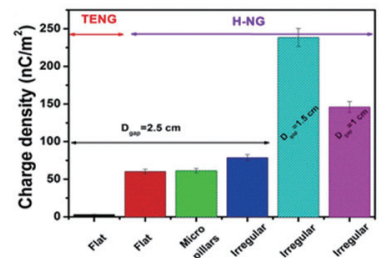

(b)

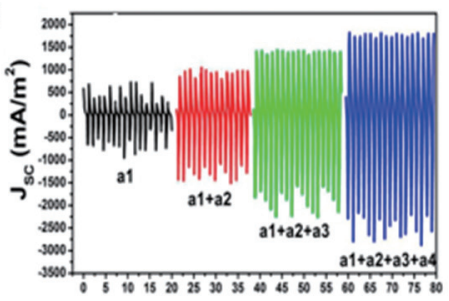

(d)
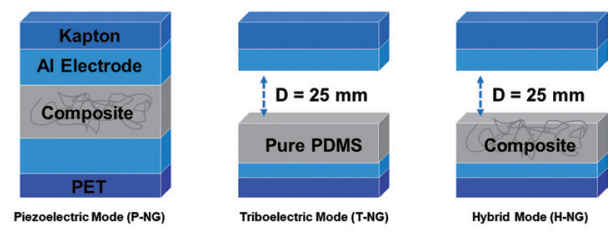

그림 14. (a) 나비날개 구조의 하이브리드 에너지 하베스터와 압전(I), 마찰(II), 그리고 하이브리드 에너지 하베스터(III)의 회로 설계 (b) 단일-/ 다중 구성의 하이브리드 에너지 하베스터의 출력 전력밀도. (c) 서로 다른 구조적 특성과 접촉-분리 간격에 따른 전하 밀도의 변화. (d) 압전 에너지 하베스터, 마찰전기 에너지 하베스터, 그리고 하이브리드 에너지 하베스터의 도식도 ${ }^{98)}$.

(a)
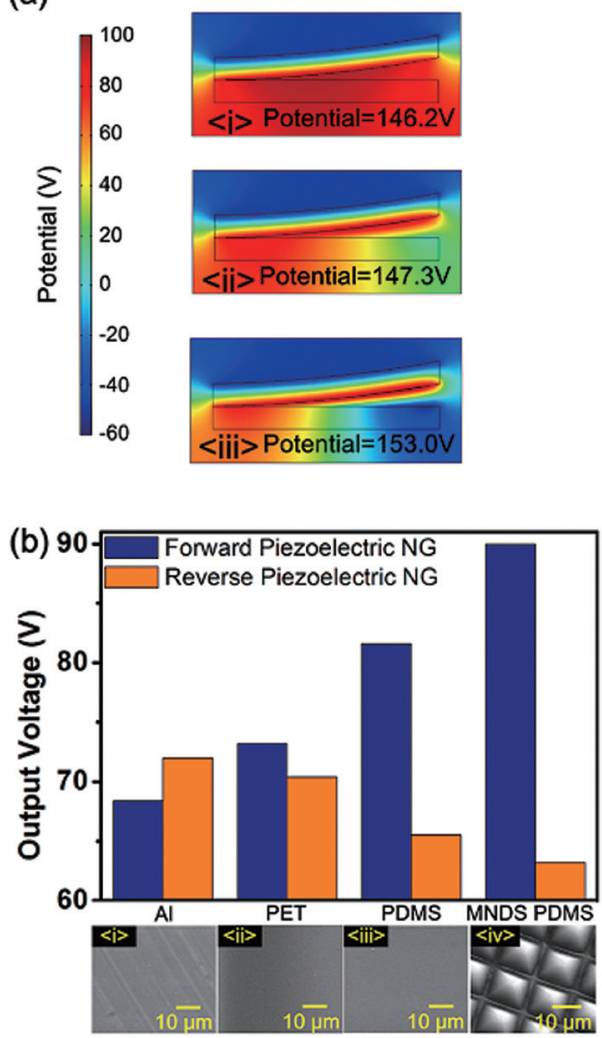

그림 15. (a) 서로 다른 표면 전하 밀도((i) $0 \mu \mathrm{Cm}^{-2}$, (ii) $10 \mu \mathrm{Cm}^{-2}$, and (iii) $20 \mu \mathrm{Cm}^{-2}$ )에서의 출력 전압 시뮬레이션. (b) 기 판 물질 변화에 따라((i) Al, (ii) PET, (iii) PDMS, and (iv) MNDS- PDMS). 주황색 기둥은 역방향으로 분극된 압전 나노발전기를 보여준다. 파란색 기둥은 전방향으로 분극된 압전 나노발전기를 보여준다. 히스토그램 아래는 네 종류 의 서로 다른 기판 표면의 전자주사현미경 이미지 $\left.\right|^{31)}$.
전 층과 마찰전기 발전층의 구조적 특성을 극대화시키 는데 이용될 수 있다. 이들은 피라미드 형태의 마이크 로 구조체와 출력 성능에 대한 상관관계를 실험과 시뮬 레이션 결과에 기반하여 탐구하였다 (그림 $15 \mathrm{~b}$ (iv) 참 조). 여기에 따르면, 복합체의 PVDF 하부면은 양으로 대전되며, 동일한 정도로 반대 전하가 그 아래의 $\mathrm{PDMS}$ 층 위에 형성된다. 이들은 그림 $15 \mathrm{a}$ (i)에서 보여지는 것 처럼 압전 효과에 의한 전압이 PVDF의 구부림에서 발 생하는 것을 관측하였다. 상하부 층의 전하 밀도가 증가 될 때, 압전 전압은 그림 $15 \mathrm{a}$ (ii)에서 보여지는 것처럼 마찬가지로 증가한다. 전하 밀도가 $10 \mu \mathrm{Cm}^{-2}$ 에서 $20 \mu$ $\mathrm{Cm}^{-2}$ 로 증가한 후에 압전 전위차가 증가하는 것이 관측 되었으며, 전압은 $146.2 \mathrm{~V}$ 에서 $153 \mathrm{~V}$ 로 증가하였다. 이 들은 또한 서로 다른 마찰층을 통해 전하 밀도가 변화 하는 것을 실험적으로 증명하였다. 특히, 출력 성능에 서 분극 방향이 중대한 역할을 하는데, 이들에 따르면 PVDF가 반대로 분극된다면 전극에 낮은 전위차와 함 께 남아있던 마찰전기 전하로 인해 출력 전압은 급격히 감소할 것이다 (그림 $15 \mathrm{~b}$ 참조). 이들이 소자에 이용한 $\mathrm{PVDF}$ 와 PDMS의 복합체는 단지 압전 에너지 하베스 터와 마찰전기 에너지 하베스터 뿐만 아니라, 압전-마 찰전기 하이브리드 에너지 하베스터에도 일반적으로 선 호되는 물질이다. 표 4 는 하이브리드 에너지 하베스터 


\section{특 집 ㅁ Aamir Rasheed, 박현제, 손민균, 이태형, 강대준}

표 4. 압전-마찰전기 하이브리드 에너지 하베스터에 이용된 다양한 물질들과 출력 성능

\begin{tabular}{|c|c|c|c|}
\hline \multirow{2}{*}{ 보고 연도 } & \multicolumn{2}{|c|}{ 이용 물질 } & \multirow{2}{*}{ 출력 성능 } \\
\hline & 압전 물질 & 마찰대전 물질 & \\
\hline $2012^{133)}$ & $\mathrm{ZnO}$ 나노와이어 & $\mathrm{PE}$ 필름 & $8 \mathrm{~V}, 2.5 \mu \mathrm{A}$ \\
\hline $2013^{31)}$ & PVDF & 알루미늄, PDMS & $\begin{array}{l}\text { 압전 에너지 하베스터: } 52.8 \mathrm{~V}, 10.95 \mathrm{mWcm}^{-3} \\
\text { 마찰전기 에너지 하베스터: } 240 \mathrm{~V}, 2.04 \mathrm{mWcm}^{-3}\end{array}$ \\
\hline $2013^{100)}$ & PVDF & PDMS & $20 \mathrm{~V}$ \\
\hline $2014{ }^{139)}$ & $\mathrm{ZnO}$ & $\mathrm{PDMS}, \mathrm{Cu}$, 나일론 & $\begin{array}{l}\text { 압전 에너지 하베스터: } 10.2 \mathrm{mWm}^{-2} \\
\text { 마찰전기 에너지 하베스터: } 42.6 \mathrm{mWm}^{-2}\end{array}$ \\
\hline $2014^{134)}$ & $\mathrm{BaTiO}_{3}, \mathrm{MWCNT}$ & PDMS, PET & $22 \mathrm{~V}, 9 \mu \mathrm{A}, 1.13 \mu \mathrm{Acm}^{-2}$ \\
\hline $2014^{137)}$ & PVDF & 구리, 알루미늄 & $215 \mathrm{~V}, 7.55 \mu \mathrm{Acm}^{-2}$ \\
\hline $2015^{142)}$ & PVDF & PDMS, MWCNT & $\begin{array}{l}\text { 압전 에너지 하베스터: } 6 \mathrm{~V} \\
\text { 마찰전기 에너지 하베스터: } 30 \mathrm{~V}\end{array}$ \\
\hline $2015^{124)}$ & $\mathrm{P}(\mathrm{VDF}-\mathrm{TrFE})$ & PDMS, MWCNT & $\begin{array}{l}\text { 압전 에너지 하베스터: } 5 \mathrm{~V}, 96.66 \mu \mathrm{W}, 1.98 \mathrm{mWcm}^{-3} \\
\text { 마찰전기 에너지 하베스터: } 30 \mathrm{~V}, 9.74 \mu \mathrm{W}, 0.689 \mathrm{mWcm}^{-3}\end{array}$ \\
\hline $2015^{28)}$ & PVDF & PTFE, 알루미늄 & $370 \mathrm{~V}, 12 \mu \mathrm{Acm}^{-2}$ \\
\hline $2015^{136)}$ & PVDF & 전도성 직물 & $210 \mathrm{~V}, 2.1 \mathrm{~mW}, 45 \mu \mathrm{A}$ \\
\hline $2015^{135)}$ & 은 나노와이어, $\mathrm{ZnO}$ & PMMA & $38.4 \mathrm{~V}, 3.2 \mu \mathrm{Acm}^{-2}$ \\
\hline $2016^{33)}$ & BTO, PDMS & $\mathrm{Cu}, \mathrm{PET}$ & $3.3 \mathrm{~V}$ \\
\hline $2016^{24)}$ & $\mathrm{P}(\mathrm{VDF}-\mathrm{TrFE})$ 나노섬유 & PDMS, MWCNT & $25 \mathrm{~V}, 98.56 \mu \mathrm{W}, 1.98 \mathrm{mWcm}^{-3}$ \\
\hline $2017^{123)}$ & $\begin{array}{l}\mathrm{P}(\mathrm{VDF}-\mathrm{TrFE}) \text { 나노섬유, } \\
\text { 은 나노와이어 }\end{array}$ & PDMS, 그라파이트 & $190 \mathrm{~V}, 16.46 \mu \mathrm{W}$ \\
\hline $2017^{143)}$ & BTO, PDMS & PTFE, MWCNT & $280 \mathrm{~V}, 20 \mu \mathrm{A}$ \\
\hline $2017^{144)}$ & $\mathrm{PDMS}, \mathrm{ZnSnO}_{3}$ & $\mathrm{Cu}, \mathrm{PDMS}$ & $300 \mathrm{~V}, 16 \mathrm{mAcm}^{-2}, 10.41 \mathrm{mWcm}^{-2}$ \\
\hline $2019^{132)}$ & $\mathrm{P}(\mathrm{VDF}-\mathrm{TrFE})$ & 폴리우레탄, PTFE & $90 \mathrm{~V}, 11 \mu \mathrm{A}$ \\
\hline $2019^{141)}$ & $400 \mu \mathrm{m}$ 두께의 Zn 필름 & $\mathrm{Cu}, \mathrm{PCB}, \mathrm{PDMS}$ & $130 \mathrm{~V},(8 \mathrm{~Hz}$ 에서 $) 4 \mu \mathrm{A}, 8.34 \mathrm{mWm}^{-2}$ \\
\hline $2019^{130)}$ & BTO, MWCNT & $\mathrm{Ni}$, 셀룰로오스 나노섬유 & $18 \mathrm{~V}, 1.6 \mu \mathrm{Acm}^{-2}$ \\
\hline
\end{tabular}

에서 이용된 물질들을 요약해서 보여준다. 다양한 물질 들이 이론적으로 이용 가능하지만, 특히, $\mathrm{ZnO}$ 나 $\mathrm{PVDF}$ (또는 $\mathrm{P}(\mathrm{VDF}-\mathrm{TrFE})$ 가 압전 물질로 자주 이용되는 것 을 알 수 있다. 두 물질 모두 우수한 압전 특성을 지니고 있지만, 최근에는 에너지 하베스터와 유연 소재 또는 착 복 소재로의 응용연구가 활발히 진행됨에 따라 유연성 을 내보이는 $\mathrm{PVDF}$ 나 이외의 압전 고분자 물질들이 점 차 널리 이용되고 있다.

\section{6. 압전-마찰전기 에너지 하베스터의 성능 향상을 위한 핵심 요소들}

압전-마찰전기 복합체 기반 에너지 하베스터의 발전 은 최근까지 각광받는 연구 분야로 다기능성, 고민감도 센서, 초소형의, 에너지 효율적인 마이크로/나노시스템
에 막대한 영향을 줄 것으로 기대된다. 사실 이 분야는 초기에 많은 연구방향을 제시하였다. 여러 학문적, 산업 적 노력들은 이 하이브리드 에너지 하베스터 기술 발전 에 전념하였으나, 점차 새로운 문제들에 직면하게 되었 다. 자가발전 소자의 근본적인 부분은 센서 네트워크와 휴대용 전자기기에 전력을 공급하기 위한 신뢰성 있는 에너지 원천을 이용하는 것이다. 서로 다른 유형의 에너 지 하베스터의 하이브리드화는 센서 노드뿐만이 아니라 주변 에너지 원천을 다양하게 수확하고 효과적으로 착 복가능한 소자들을 충전할 수 있는 효과적인 접근법으 로 간주된다. 물질의 분극 방향은 또다른 중요한 요소이 다. 아래방향의 분극 방향은 윗방향과의 비교에서 $30 \%$ 증가한 성능 개선을 보였는데, 이는 두 유형의 에너지 하베스터들의 출력 전압이 방향적으로 동일해 아래 분 


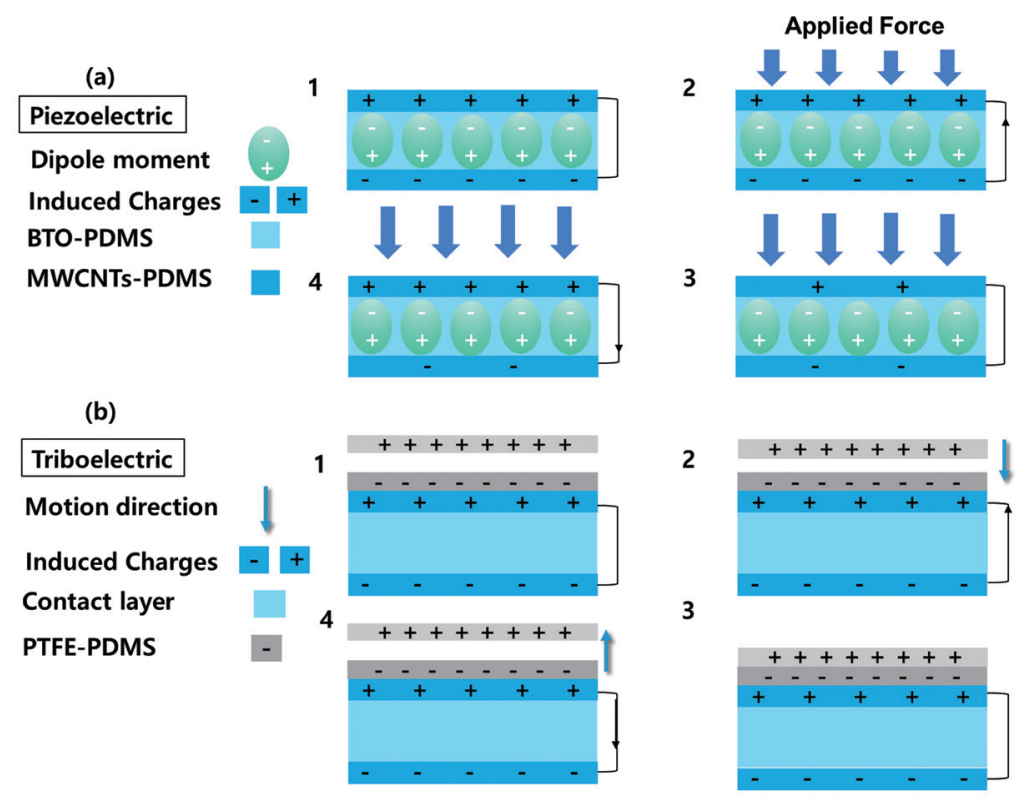

그림 16. 아래 방향의 분극에서 압전 에너지 하베스터(a)와 마찰전기/압전-마찰전기 에너지 하베스터(b)의 작동 원리 ${ }^{143)}$.

극 방향에서 쉽게 결합가능하기 때문이다 (그림 $16 \mathrm{a}$ 와 b). ${ }^{143)}$

압전-마찰전기 하이브리드 에너지 하베스터는 소자 의 제작 설계 과정이 매우 복잡하다. 가령, 앞서 언급한 것처럼 교류 형태의 전기적 출력 신호는 타 전자기기의 작동을 위해 직류로 변환될 필요가 있는데, 이에 소자상 에 부가되는 정류기는 하이브리드 소자의 단순성을 저 해할 뿐만이 아니라 전체적인 출력 성능을 감소시킨다.

구조적 단순화를 위해서는 일반적인 압전-마찰전 기 복합체 이외에도 압전 효과와 마찰전기 효과 모두 를 내보이는 단일 물질 이용이 선호되며, 이에 관한 연 구 또한 이미 진행되고 있다. ${ }^{98) 142-143)}$ 하이브리드 에너 지 하베스터에서 압전-마찰전기 나노복합체를 나노 필러 이용으로 합성하는 경우 이때의 필러의 무게 비 율은 매우 중요한 요소이다. 과다한 필러 첨가는 응집 (agglomeration)으로 인해 성능의 저하를 야기하는데, 필러의 응집은 인가되는 힘을 불균일하게 전달하여 복 합체에서 전기적 쌍극자 배열의 균일도를 저하시키기 때문이다. 결국 이는 전기적 쌍극자들을 상쇄시킬 정도 로 낮은 전기적 출력의 원인이 된다. ${ }^{98)}$

마찰전기 에너지 하베스터는 높은 내부저항을 지니는
데, 이 요소로 인해 출력 전압은 높게 나타난다. 그러나, 반대로 출력 전류는 이에 비해 높지 않다. 식 1은 내부 저항과 외부 출력 사이의 관계를 분명히 보여준다.

$$
P=\left(\frac{V}{R_{\text {in }}+R_{e x}}\right)^{2} \times R_{e x}
$$

$\left(\mathrm{P}, \mathrm{V}, \mathrm{R}_{\mathrm{in}}\right.$, 그리고 $\mathrm{R}_{\mathrm{ex}}$ 는 각각 에너지 하베스터의 전 력, 전압, 내부저항, 그리고 외부저항)

외부 저항과 내부 저항의 일치는 마찬가지로 소자 출 력에서 간과할 수 없는 요소이다. 만약 두 저항이 동일 하다면 이론적으로 출력 전력은 최대값을 가질 수 있다. 따라서 소자 통합을 위해서는 마찰전기 에너지 하베스 터의 내부 저항을 감소시킬 필요가 있다. 그러나 문제는 두 에너지 하베스터를 통합시키는 과정에서 내부저항과 외부저항 사이의 불일치가 빈번하게 발생한다는 것이 다. 표 5 는 최적화된 출력 성능을 내보이는 저항값들을 보여준다. 여기서 알 수 있듯이, 최고의 출력을 산출하 기 위해 요구되는 저항은 수 $\mathrm{k} \Omega$ 에서 수백 $\mathrm{M} \Omega$ 에 이른 다. 즉, 하이브리드 소자 제작에 있어서 조합되는 압전 물질과 마찰전기 물질의 합성과 그 합성 과정에 따라 최 


\section{특 집 ㅁㅁ Aamir Rasheed, 박현제, 손민균, 이태형, 강대준}

표 5. 압전-마찰전기 하이브리드 에너지 하베스터에서 최적화된 일치 저항(matched resistance)과 작동 진동수

\begin{tabular}{|c|c|c|c|c|}
\hline 최적화된 일치 저항 & 압전 물질 & 마찰대전 물질 & 작동 진동수 & 출력 성능 \\
\hline $5 \sim 30 \mathrm{M} \Omega^{124)}$ & PVDF-TrFE 나노와이어 & $\begin{array}{l}\text { PDMS-MWCNT 나노복 } \\
\text { 합체 }\end{array}$ & $1 \sim 4 \mathrm{~Hz}$ & $\begin{array}{l}17.5 \sim 25 \mathrm{~V}, 98.56 \mu \mathrm{W}(5 \mathrm{M} \Omega), \\
9.747 \mu \mathrm{W}(30 \mathrm{M} \Omega)\end{array}$ \\
\hline $1 \mathrm{k} \Omega \sim 10 \mathrm{M} \Omega^{144)}$ & $\mathrm{PDMS}-\mathrm{ZnSnO}_{3}$ 나노큐브 & $\mathrm{Cu}, \mathrm{PDMS}$ & 손으로 가볍게 문지름 & $320 \mathrm{~V}$ \\
\hline $1 \mathrm{M} \Omega^{33)}$ & BTO-PDMS & $\mathrm{Cu}, \mathrm{PET} / \mathrm{ITO}$ & $20 \mathrm{~Hz}$ & $1.44 \mathrm{~V}$ \\
\hline $9 \mathrm{k} \Omega \sim 10 \mathrm{M} \Omega^{134)}$ & $\mathrm{BaTiO}_{3}-\mathrm{MWCNT}$ 복합체 & PDMS & $5 \sim 20 \mathrm{~Hz}$ & $22 \sim 370 \mathrm{~V}$ \\
\hline $100 \mathrm{M} \Omega^{31)}$ & PVDF & PDMS, 알루미늄 & $5 \mathrm{~Hz}$ & $\begin{array}{l}\text { 압전 에너지 하베스터: } 52.8 \mathrm{~V} \\
\text { 마찰전기 에너지하베스터: } 240 \mathrm{~V}\end{array}$ \\
\hline $22 \mathrm{M} \Omega^{145)}$ & $\mathrm{ZnO}$ & PDMS & $1 \sim 3 \mathrm{~Hz}$ & $60 \mathrm{~V}, 2.0 \mu \mathrm{A}, 50 \mu \mathrm{Wcm}^{-2}$ \\
\hline $286.7 \mathrm{M} \Omega^{129)}$ & $\mathrm{PVDF}-\mathrm{BCZT}$ 나노복합체 & $\mathrm{PVDF}-\mathrm{PCZT}$ 복합체 & $1 \sim 3 \mathrm{~Hz}$ & $42 \mathrm{~V}, 1.7 \mathrm{mAm}^{-2}$ \\
\hline $60 \sim 80 \mathrm{M} \Omega^{130)}$ & BTO, MWCNT & $\mathrm{Ni}$, 셀룰로오스 나노섬유 & $5 \mathrm{~Hz}$ & $18 \mathrm{~V}, 1.6 \mu \mathrm{Acm}^{-2}$ \\
\hline $70 \mathrm{M} \Omega^{98)}$ & $\begin{array}{l}0.3 \mathrm{Ba}_{0.7} \mathrm{Ca}_{0.3} \mathrm{TiO}_{3}- \\
0.7 \mathrm{BaSn}_{0.12} \mathrm{Ti}_{0.88} \mathrm{O}_{3} \text { 나노입자 }\end{array}$ & PDMS, 알루미늄 & $5 \mathrm{~Hz}$ & $572 \mathrm{~V}, 2500 \mathrm{mAm}^{-2}$ \\
\hline $1 \sim 15 \mathrm{M} \Omega^{41)}$ & PVDF & PDMS, MWCNT & $1 \sim 5 \mathrm{~Hz}$ & $\begin{array}{l}\text { 압전 에너지 하베스터: } 0.12 \mu \mathrm{W} \\
(1 \mathrm{M} \Omega) \\
\text { 마찰전기 에너지하베스터: } 3.4 \mu \mathrm{W} \\
(1 \mathrm{M} \Omega)\end{array}$ \\
\hline $0.6 \sim 0.9 \mathrm{M} \Omega^{148)}$ & PVDF & 알루미늄, PDMS & 바람속도: $10 \mathrm{~m} / \mathrm{s}$ & $\begin{array}{l}0.6 \mathrm{M} \Omega \text { 에서 } 112 \mu \mathrm{W} \\
0.9 \mathrm{M} \Omega \text { 에서 } 76 \mu \mathrm{W}\end{array}$ \\
\hline $2.5 \mathrm{M} \Omega^{123)}$ & $\begin{array}{l}\mathrm{P}(\mathrm{VDF}-\mathrm{TrFE}) \text { 나노섬유, } \\
\text { 은 나노와이어 }\end{array}$ & $\mathrm{PDMS}$, 그라파이트 & $3 \mathrm{~Hz}$ & $190 \mathrm{~V}$ \\
\hline
\end{tabular}

적화된 저항값이 조율되어야만 하는 것이다. 따라서 내 부저항의 최적화는 출력 성능을 개선시키기 위한 중요 한 역할을 하며, 하이브리드 소자 설계에 있어서 합리적 인 방식으로 고려되어야 한다. 이러한 맥락에서, 한 연 구는 복합체 합성에 있어 MWCNT와 그래핀의 함량 제 어를 통해 내부저항을 효과적으로 조절하는 방식을 개 진하기도 하였다. ${ }^{24)}$

하이브리드 소자에서 압전-마찰전기 복합체를 이용 하는 경우, 압전기 발생 부분을 담당하는 물질의 선택 은 합리적으로 이루어져야 한다. 가령, 그래핀과 나노입 자가 첨가된 고분자 물질의 이용은 압전기 발생 성능 뿐 만 아니라 우수한 유연성과 내구성을 지닌다는 장점 때 문에 상당히 중요한 역할을 한다. PVDF는 낮은 분극상 수와 유연성 등을 이유로 하이브리드 소자에서 압전 물 질로 많이 이용된다. 그밖에 $\mathrm{ZnO}$ 나노조각, $\mathrm{PZT}$ 전기 물질, $\mathrm{MoS}_{2}$ 등 다양한 다른 물질들이 우수한 압전 특성 을 근거로 하이브리드 소자에 이용된다. 표 4 는 하이브 리드 에너지 하베스터에 이용된 다양한 물질들을 보여 준다. 언급하였듯이, 일반적으로 압전 물질로는 $\mathrm{ZnO}$ 나
PVDF (또는 $\mathrm{P}(\mathrm{VDF}-\mathrm{TrFE})$ )가 이용되며, 마찰대전 물 질로는 $\mathrm{PDMS}$ 가 자주 선택된다. 최근에는 이용가능한 소재 범위 확대와 보다 높은 출력 성능을 위해 보다 다 양한 물질과의 합성이 널리 연구되는 추세이다. 특히, 전기전도도 향상뿐만 아니라 우수한 기계적 특성을 동 시에 지니기 위해 그래핀, 탄소나노튜브, BTO 나노입 자 등의 물질들이 복합체 제작에 자주 이용된다. 그러 나, 앞서 언급한 것처럼 복합체 제작 과정에서 과도한 물질 첨가는 도리어 복합체 응집으로 인해 오히려 전체 적인 출력 성능을 저하시킬 수 있으며, 합성과정에서 높 은 비용이 발생하기에 보다 세심한 고려가 요구된다. 하 이브리드 에너지 하베스터에서 복합체의 마찰전기 층 기능화와 그 구조적 특성 제어는 출력 성능을 증가시키 기 위한 또다른 중요한 요소이다. $\mathrm{NH}_{2}, \mathrm{SH}, \mathrm{CH}_{3}$, 그리 고 $\mathrm{CF}_{3}$ 등의 물질 이용은 표면의 화학적 기능화를 통해 전위차를 증가시킨다. 일반적으로, 접촉면 증가는 마찰 전하 교환의 증대로 마찰전기적 출력성능을 증가시키는 데, 복합체 표면의 패터닝을 통해 다양한 기하학적 형상 에서 출력성능이 연구되었다. ${ }^{93),{ }^{149-152)}}$ 예를 들어, 2018 
표 6. 압전-마찰전기 하이브리드 에너지 하베스터의 서로 다른 소자 형태와 출력 성능.

\begin{tabular}{|c|c|c|c|}
\hline \multirow{2}{*}{ 하이브리드 소자 구조 } & \multicolumn{2}{|c|}{ 이용 물질 } & \multirow{2}{*}{ 출력 성능 } \\
\hline & 압전 물질 & 마찰대전 물질 & \\
\hline $\mathrm{r}$-형태 ${ }^{31}$ & PVDF & PDMS, 알루미늄 & $\begin{array}{l}\text { 압전 에너지 하베스터: } 52.8 \mathrm{~V}, 10.95 \mathrm{mWcm}^{-3} \\
\text { 마찰전기 에너지 하베스터: } 240 \mathrm{~V}, 2.04 \mathrm{mWcm}^{-3}\end{array}$ \\
\hline 파도 형태 ${ }^{32)}$ & $\mathrm{P}(\mathrm{VDF}-\mathrm{TrFE})$ & $\mathrm{PDMS}$, 캡톤 필름 & $\begin{array}{l}\text { 압전 에너지 하베스터: } 47.8 \sim 96 \mathrm{~V} \\
\text { 마찰전기 에너지 하베스터: } 345.4 \sim 361.27 \mathrm{~V}\end{array}$ \\
\hline $\mathrm{d}$ 자 아치형태 ${ }^{128)}$ & PVDF & 실리콘, 알루미늄 & $25.8 \mathrm{~V}, 8.82 \mu \mathrm{A}$ \\
\hline 원호 형태 ${ }^{134)}$ & $\mathrm{BaTiO}_{3} / \mathrm{MWCNT}$ & PDMS, PET-ITO & $22 \mathrm{~V}, 9 \mu \mathrm{A}, 1.13 \mu \mathrm{Acm}^{-2}$ \\
\hline 원형 순환 형태 ${ }^{153)}$ & $\begin{array}{l}\mathrm{PVDF}-\mathrm{BTO}-\mathrm{MW}- \\
\mathrm{CNT} \text { 복합체 }\end{array}$ & 구리 & $48.46 \mathrm{~V}, 1.22 \mathrm{mAcm}^{-2}$ \\
\hline 나비날개 형태 ${ }^{98)}$ & $\begin{array}{l}0.3 \mathrm{Ba}_{0.7} \mathrm{Ca}_{0.3} \mathrm{TiO}_{3}- \\
\text { 0.7 } \mathrm{BaSn}_{0.12} \mathrm{Ti}_{0.88} \mathrm{O}_{3} \\
\text { 나노입자 }\end{array}$ & PDMS, 알루미늄 & $572 \mathrm{~V}, 1336 \mathrm{Wm}^{-2}$ \\
\hline 아치형태 ${ }^{130)}$ & BTO, MWCNT & $\begin{array}{l}\mathrm{Ni} \text {, 셀룰로오스 나노 } \\
\text { 섬유 }\end{array}$ & $18 \mathrm{~V}, 1.6 \mu \mathrm{Acm}^{-2}$ \\
\hline 아치형태 ${ }^{134)}$ & $\mathrm{BaTiO}_{3}, \mathrm{MWCNT}$ & PDMS, PET & $22 \mathrm{~V}, 9 \mu \mathrm{A}, 1.13 \mu \mathrm{Acm}^{-2}$ \\
\hline Flat panel 형태 ${ }^{14)}$ & $\mathrm{PDMS}, \mathrm{ZnSnO}_{3}$ & $\mathrm{Cu}, \mathrm{PDMS}$ & $300 \mathrm{~V}, 16 \mathrm{mAcm}^{-2}, 10.41 \mathrm{mWcm}^{-2}$ \\
\hline
\end{tabular}

년 본 연구진은 3 차원 그래핀 구조체를 제작하여 압전 물질(ZnO 나노조각)과 마찰대전 물질(PDMS) 복합체의 구조적 틀로 이용하는 방법을 제안하였다. ${ }^{154)}$ 여기에 따 르면 3차원 그래핀은 넓은 표면적을 가지고 있어 압전효 과와 마찰대전 효과를 상당한 수준에서 증가시킬 수 있 으며, 유연성과 기계적 강도 등의 그래핀 본유의 우수한 물성도 이용 가능하다는 장점을 보인다.

초기 하이브리드 소자 설계는 복합체에서 압전 물질 의 한 면만을 이용하였으나, 여기에 대한 개선, 즉 압전 물질의 양 면을 이용하는 것은 출력 성능을 보다 증가시 키는데 이용될 수 있다. ${ }^{32)}$ 게다가, 두 에너지 하베스터 유형의 다양한 구조적 설계들 중에서, 기저 전극과 세로 방향의(longitudinal) 압전 에너지 하베스터로 구성된 단일 전극 마찰전기 에너지 하베스터는 유사한 소자 구 조 내에서 에너지 수확 메커니즘의 하이브리드화가 쉽 게 구현될 수 있다. ${ }^{155)}$ 또한 곡면 또는 미세 패턴이 형성 된 마찰전기 표면의 하이브리드 소자는 낮은 작동 진동 수와 출력 전압의 증가를 위해 보다 다양한 소자 설계가 선호될 수 있다. 이 경우 곡면은 소자에 추가적인 유연 성을 주는데, 낮은 진동수의 에너지 수확에 우수한 성능 을 보인다. ${ }^{98)}$ 게다가, 곡면은 접촉-분리 단계에서 평면 에 비해 쉽게 되돌아올 수 있다. 하이브리드 소자에서,
압전 발전 층이 $r$-형태, 아치 형태, 또는 이중 아치형태 를 유지한다면, 작은 외부 자극만으로도 효과적으로 물 질 내부의 분극화를 유도할 수 있다. 출력 성능은 분극 방향, 전극 연결, 그리고 구조적 특성에 크게 의존한다. 소자의 구조에 대하여, 비슷한 분극 방향에서 소자의 성 능은 증가한다. 이러한 다양한 소자 구조에 대한 출력 성능은 표 6 에 요약 정리되어 있다. 비록 복합체 합성에 서 물질의 선택과 소자 구조 설계에 따라 높은 출력의 하이브리드 에너지 하베스터가 제작 가능하지만, 복잡 한 소자 구조에는 연성과 탄성력이 우수한 고분자 기반 의 나노복합체가 선호되는데, 이 경우 복잡하고 고가의 물질 합성법이 요구된다는 단점이 내재한다.

\section{5. 정리 및 전망}

본고는 에너지 하베스터의 하이브리드화에 대한 발 전 현황을 살펴보았다. 특히, 에너지 하베스터의 실용화 를 위해 출력 성능 개선에 대한 여러 논의를 진행하였는 데, 단순히 소자 설계뿐만 아니라 작동 진동수, 물질 선 택, 임피던스 등 여러 주요 매개변수들의 영향력을 함께 살펴보았다. 에너지 하베스터는 처음 개발된 이후로 지 속적인 연구를 통해 출력 성능에서 상당한 진전을 보였 


\section{특 집 ㅍ Aamir Rasheed, 박현제, 손민균, 이태형, 강대준}

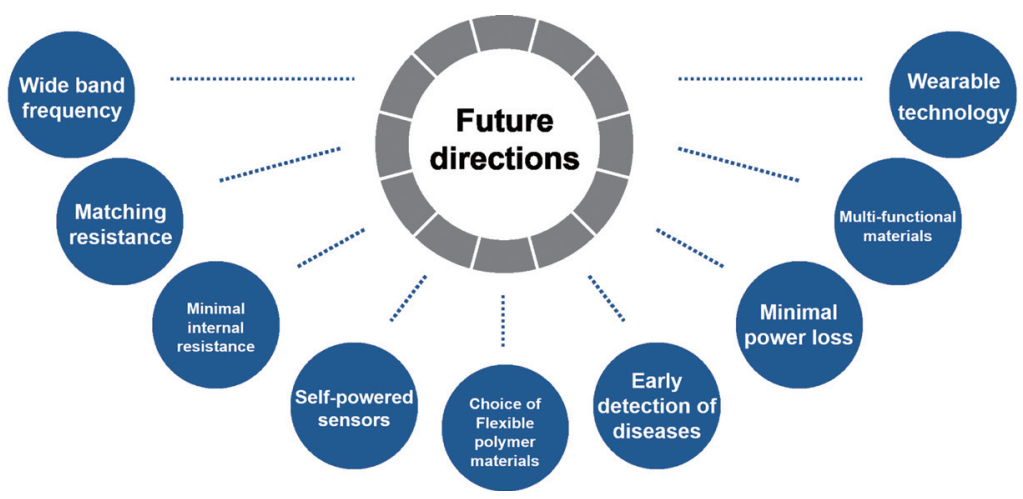

그림 17. 앞으로의 전망과 남는 문제들.

으나.6), ${ }^{84)}$ 대표적인 에너지 하베스터인 마찰전기 에너 지 하베스터와 압전 에너지 하베스터가 각각 출력 전류 밀도와 출력 전압에서 분명한 한계를 지닌다는 것이 지 적되었다. 이에 기계적 에너지를 수확하는 서로 다른 메 커니즘들이 소자 내부에 동시적으로 구현되어 출력 성 능을 효과적으로 향상시키는 '에너지 하베스터의 하이브 리드화'가 주된 연구주제로 떠올랐고, 현재까지 진행 중 에 있다. 특히, 압전-마찰전기 하이브리드 에너지 하베 스터는 두 유형의 에너지 하베스팅 소자들의 장점은 유 지하되 단점을 극복하는 특징을 내보이기에 우수한 출 력 성능은 물론, 응용가능성이나 소자의 추가적인 기능 성 등에서도 밝은 전망을 내보이고 있다. 그럼에도 불구 하고 이러한 하이브리드 소자의 작동원리에 대한 분명 한 이해는 여전히 부족하며, 그 응용가능성이나 출력 성 능에서 현재 수준 이상의 개선이 가능한지에 대한 여부 는 앞으로의 연구과제로 남아있다. 그림 17은 압전-마 찰전기 하이브리드 에너지 하베스터 연구에 있어 앞으 로의 연구 방향성과 해결해야 할 과제들을 나타낸다.

무엇보다도 작동 진동수의 제한적인 범위는 간과할 수 없다. 지금까지 보고된 대부분의 에너지 하베스터들 은 비교적 높은 작동 진동수에서 에너지를 수확한다. 그 러나 접근가능한 자연적 에너지원에서는 대개 $50 \mathrm{~Hz}$ 이하의 낮은 진동수를 내보이는데(예를 들어, 산들바람 이나 가벼운 손짓), 앞으로의 연구는 $1 \sim 60 \mathrm{~Hz}$ 범위 내 에서도 최적의 작동 진동수를 내보이는 에너지 하베스 터 개발에 집중될 것으로 예상할 수 있다. 보다 넓은 진
동수 범위에서 에너지 하베스터를 작동시키기 위해, 고 분자와 금속류가 코팅된 유연기판과 적절한 강도를 유 지하는 동시에 유연성과 경량성을 보이는 물질이 중요 한 역할을 할 것이다. 이러한 물질의 이용은 외부 기계 적 힘에 있어서 소자가 “스프링”과 같은 역할을 하도록 하는데, 이러한 스프링-질량계에서는 보다 넓은 범위의 진동수에서 역학적 에너지를 수확하는 것이 가능해진 다. 또한, 작은 외부 힘으로 작동하는 마찰전기 에너지 하베스터의 단독 슬라이딩 방식도 주목할 만하다.

앞서 언급하였듯이, 하이브리드 소자에서 내부저항의 불일치는 출력 전력을 감소시키는 문제를 발생시킨다. 보통 마찰전기 에너지 하베스터가 압전 에너지 하베스 터보다 더 높은 내부저항을 지니는데, 두 유형의 소자들 을 적절하게 통합시키기 위해서는 이 내부저항이 매우 중요한 요소로 작용한다. 게다가, 외부저항과 내부저항 은 크기에 있어서 일치되어야 하는데, 보다 높은 출력을 위해서는 마찰전기 에너지 하베스터의 내부저항을 줄이 는 동시에 외부저항과의 일치를 도모할 독창적인 접근 법이 요구된다.

하이브리드 에너지 하베스터의 적절한 출력 성능과 다기능성은 특히나 자가발전 가능한 생체이식 바이오 센서나 실시간 건강 모니터링 시스템에 이용될 수 있다. 그러나, 현재까지 압전-마찰전기 하이브리드 에너지 하 베스터를 통한 의료장치로의 응용은 실용적 관점에서 한계가 있다. 왜냐하면 앞서 언급한 작동 진동수의 문제 와 연관 지어, 근육의 수축, 혈류, 심장박동, 눈 깜빡임 
등의 생체 에너지를 수확하기에는 너무 낮은 진동수가 주어지기 때문이다. 또한, 생체 이식 소자로서 감염과 같은 문제를 피하기 위해서는 복합체 제작 시에 생체적 합성은 물론, 무독성과 생분해성 등을 충분히 지니는 물 질들을 선택해야 한다.

이처럼 응용소자로서 역할을 고려한다면 이용 물질 의 신중한 선택은 필연적이다. 일반적으로, 각종 고분자 물질, 나노섬유, 탄소나노튜브, 2차원 물질 등은 우수 한 수준의 기계적 강도, 유연성, 경량성, 그리고 전기전 도도 등의 특성을 내보일 수 있는데, 하이브리드 에너지 하베스터의 시너지 효과나 소자의 다기능성 실현에 있 어서 훌륭한 선택지로 고려될 수 있다. 한 예로, PVDF 나 $\mathrm{P}(\mathrm{VDF}-\mathrm{TrFE})$ 와 같은 고분자는 유연한 압전 물질 로 잘 알려져 있지만 동시에 마찰전기 발생을 위한 물질 로도 이용이 가능하다. 또한 은, 구리, 그리고 알루미늄 등의 몇몇 금속류는 전극뿐만 아니라 마찰전기층으로의 이용을 가능하게 하기에, 여기에 대한 고려는 소자의 단 순한 구성과 제작 비용에서 이점을 보일 수 있다.

소자 구조 설계의 단순화는 산출되는 에너지의 불필 요한 낭비나 공정 과정에서 비용을 최소화하기 위해 요 구된다. 특히, 일반 전자기기로 이용되기 위해 교류 형 태의 출력 신호는 직류 형태로 변환되어야 하는데, 이때 정류기와 같은 별도 장치의 추가는 소자 구성을 복잡하 게 하여 불필요한 전력 소모를 발생시킨다. 이에 다양한 방식에서 단순한 소자 설계에 대한 연구가 요구된다.

마지막으로, 소자 제작에 있어 작동 환경에 대한 고려 도 이루어져야 한다. 온도나 습기, 또는 반복적 작동에 따른 발열 등에 취약한 소재는 에너지 하베스터로서 이 용을 삼가야 한다. 특히, 두 가지의 에너지 수확 메커니 즘을 실현하는 압전-마찰전기 복합체 기반의 하이브리 드 에너지 하베스터의 경우, 압전 효과와 마찰전기 효과, 어느 한 쪽도 간과되어서는 안 되기에 해당 물질 이용에 있어서 환경적 고려가 보다 세심하게 이루어져야 한다.

\section{REFERENCES}

1. B. W. An, J. H. Shin, S.-Y. Kim, J. Kim, S. Ji, J. Park, Y. Lee, J. Jang, Y.-G. Park, and
E. Cho, "Smart Sensor Systems for Wearable Electronic Devices," Polymers 9, 303 (2017).

2. A. Kaushik, R. Kumar, S. K. Arya, M. Nair, B. Malhotra, and S. Bhansali, "Organic-inorganic hybrid nanocomposite-based gas sensors for environmental monitoring," Chem. Rev. 115, 4571-4606 (2015)

3. L. Y. Chen, B. C. -K. Tee, A. L. Chortos, G. Schwartz, V. Tse, D. J. Lipomi, H.-S. P. Wong, M. V. McConnell, and Z. Bao, "Continuous wireless pressure monitoring and mapping with ultra-small passive sensors for health monitoring and critical care," Nat. Commun. 5, 5028 (2014).

4. M. Sitti, H. Ceylan, W. Hu, J. Giltinan, M. Turan, S. Yim, and E. Diller, "Biomedical applications of untethered mobile milli/ microrobots," Proc. IEEE. 103, 205-224 (2015).

5. Z. L. Wang and W. Wu, "Nanotechnologyenabled energy harvesting for self-powered micro-/nanosystems," Angew. Chem. 51, 11700-11721 (2012)

6. Z. L. Wang and J. Song, "Piezoelectric nanogenerators based on zinc oxide nanowire arrays," Science. 312, 242-246 (2006)

7. V. Nguyen, R. Zhu, and R. Yang, "Environmental effects on nanogenerators," Nano Energy. 14, 49-61 (2015).

8. K. Y. Lee, D. Kim, J. H. Lee, T. Y. Kim, M. K. Gupta, and S. W. Kim, "Unidirectional HighPower Generation via Stress-Induced Dipole Alignment from ZnSnO3 Nanocubes/Polymer Hybrid Piezoelectric Nanogenerator," Adv. Func. Mater. 24, 37-43 (2014)

9. J.-H. Lee, K. Y. Lee, B. Kumar, N. T. Tien, N.-E. Lee, and S. - W. Kim, "Highly sensitive stretchable transparent piezoelectric nanogenerators," Energy Environ. Sci. 6, 169175 (2013)

10. J. H. Lee, H. Ryu, T. Y. Kim, S. S. Kwak, H. J. Yoon, T. H. Kim, W. Seung, and S. W. Kim, "Thermally Induced Strain-Coupled Highly Stretchable and Sensitive Pyroelectric Nanogenerators," Adv. Energy. Mater. 5 (2015)

11. J. H. Lee, K. Y. Lee, M. K. Gupta, T. Y. Kim, D. Y. Lee, J. Oh, C. Ryu, W. J. 
Yoo, C. Y. Kang, and S. J. Yoon, "Highly stretchable piezoelectric-pyroelectric hybrid nanogenerator," Adv. Mater. 26, 765-769 (2014)

12. K. Y. Lee, S. K. Kim, J. H. Lee, D. Seol, M. K. Gupta, Y. Kim, and S. W. Kim, "Controllable charge transfer by ferroelectric polarization mediated triboelectricity," Adv. Func. Mater. 26, 3067-3073 (2016)

13. J. H. Lee, R. Hinchet, S. K. Kim, S. Kim, and S. -W. Kim, "Shape memory polymer-based self-healing triboelectric nanogenerator," Energy Environ. Sci. 8, 3605-3613 (2015)

14. W. Seung, M. K. Gupta, K. Y. Lee, K.-S. Shin, J.-H. Lee, T. Y. Kim, S. Kim, J. Lin, J. H. Kim, and S.-W. Kim, "Nanopatterned textile-based wearable triboelectric nanogenerator," ACS Nano. 9, 3501-3509 (2015)

15. X. Yang and W. A. Daoud, "Triboelectric and Piezoelectric Effects in a Combined TriboPiezoelectric Nanogenerator Based on an Interfacial ZnO Nanostructure," Adv. Func. Mater. 26, 8194-8201 (2016)

16. Yang, Y., et al., Flexible hybrid energy cell for simultaneously harvesting thermal, mechanical, and solar energies. ACS Nano 7, 785-790 (2012).

17. F. R. Fan, W. Tang, and Z. L. Wang, "Flexible nanogenerators for energy harvesting and self-powered electronics," Adv. Mater. 28, 4283-4305 (2016)

18. J.-H. Lee, J. Kim, T. Y. Kim, M. S. Al Hossain, S. -W. Kim, and J. H. Kim, "All-inone energy harvesting and storage devices," J. Mater. Chem. A. 4, 7983-7999 (2016)

19. Q. Zheng, B. Shi, Z. Li, and Z. L. Wang, "Recent Progress on Piezoelectric and Triboelectric Energy Harvesters in Biomedical Systems," Adv. Sci. 4, 1700029 (2017).

20. Z. L. Wang, G. Zhu, Y. Yang, S. Wang, and C. Pan, "Progress in nanogenerators for portable electronics," Materials Today 15, 532-543 (2012)

21. J. Lowell and A. Rose-Innes, "Contact electrification,” Adv. Phys. 29, 947-1023 (1980)
22. G. Castle, "Contact charging between insulators,” J. Electrostat. 40, 13-20 (1997).

23. R. Yang, Y. Qin, L. Dai, and Z. L. Wang, "Power generation with laterally packaged piezoelectric fine wires," Nat. Nanotechnol. 4, 34 (2009)

24. X. Wang, B. Yang, J. Liu, Y. Zhu, C. Yang, and Q. He, "A flexible triboelectricpiezoelectric hybrid nanogenerator based on $\mathrm{P}$ (VDF-TrFE) nanofibers and PDMS/MWCNT for wearable devices," Sci. Rep. 6, 36409 (2016)

25. S. Roundy and E. Takahashi, "A planar electromagnetic energy harvesting transducer using a multi-pole magnetic plate," Actuator A Phys. 195, 98-104 (2013)

26. L. Gu, N. Cui, L. Cheng, Q. Xu, S. Bai, M. Yuan, W. Wu, J. Liu, Y. Zhao, and F. Ma, "Flexible fiber nanogenerator with $209 \mathrm{~V}$ output voltage directly powers a lightemitting diode," Nano. lett. 13, 91-94 (2012)

27. G. Zhu, A. C. Wang, Y. Liu, Y. Zhou, and Z. L. Wang, "Functional electrical stimulation by nanogenerator with $58 \mathrm{~V}$ output voltage," Nano. lett. 12, 3086-3090 (2012)

28. W.-S. Jung, M.-G. Kang, H. G. Moon, S. - H. Baek, S.-J. Yoon, Z. -L. Wang, S. - W. Kim, and C. - Y. Kang, "High output piezo/ triboelectric hybrid generator," Sci. Rep. 5, 9309 (2015)

29. H. Van Ngoc and D. J. Kang, "Flexible, transparent and exceptionally high power output nanogenerators based on ultrathin $\mathrm{ZnO}$ nanoflakes," Nanoscale 8, 5059-5066 (2016)

30. Y. Zi, L. Lin, J. Wang, S. Wang, J. Chen, X. Fan, P. K. Yang, F. Yi, and Z. L. Wang, "Triboelectric-Pyroelectric-Piezoelectric Hybrid Cell for High-Efficiency EnergyHarvesting and Self-Powered Sensing," Adv. Mater. 27, 2340-2347 (2015)

31. M. Han, X.-S. Zhang, B. Meng, W. Liu, W. Tang, X. Sun, W. Wang, and H. Zhang, " $r$-Shaped hybrid nanogenerator with enhanced piezoelectricity," ACS Nano. 7, 8554-8560 (2013)

32. X. Chen, M. Han, H. Chen, X. Cheng, 
Y. Song, Z. Su, Y. Jiang, and H. Zhang, "A wave-shaped hybrid piezoelectric and triboelectric nanogenerator based on $\mathrm{P}$ (VDFTrFE) nanofibers," Nanoscale 9, 1263-1270 (2017)

33. G. Suo, Y. Yu, Z. Zhang, S. Wang, P. Zhao, J. Li, and X. Wang, "Piezoelectric and triboelectric dual effects in mechanical-energy harvesting using BaTiO3/polydimethylsiloxane composite film," ACS Appl. Mater. Interfaces 8, 34335-34341 (2016)

34. C. Xu, X. Wang, and Z. L. Wang, "Nanowire structured hybrid cell for concurrently scavenging solar and mechanical energies," J. Amer. Chem. Soc. 131, 5866-5872 (2009)

35. P. Li, S. Gao, H. Cai, and L. Wu, "Theoretical analysis and experimental study for nonlinear hybrid piezoelectric and electromagnetic energy harvester," Micro. syst. Technol. 22, 727-739 (2016)

36. X. Wu, A. Khaligh, and Y. Xu, "Modeling, design and optimization of hybrid electromagnetic and piezoelectric MEMS energy scavengers" Paper presented in IEEE Custom Integrated Circuits Conference in San Jose, CA, USA (177-80), 2008

37. J. He, T. Wen, S. Qian, Z. Zhang, Z. Tian, J. Zhu, J. Mu, X. Hou, W. Geng, and J. Cho, "Triboelectric-piezoelectric-electromagnetic hybrid nanogenerator for high-efficient vibration energy harvesting and self-powered wireless monitoring system," Nano Energy. 43, 326-339 (2017)

38. B. P. Nabar, Z. Çelik-Butler, and D. P. Butler, "Piezoelectric ZnO nanorod carpet as a NEMS vibrational energy harvester," Nano Energy. 10, 71-82 (2014).

39. H. Liu, C. J. Tay, C. Quan, T. Kobayashi, and C. Lee, "Piezoelectric MEMS energy harvester for low-frequency vibrations with wideband operation range and steadily increased output power," J. Micro Electromech. S. 20, 1131$1142(2011)$

40. B. Yang, C. Lee, R. K. Kotlanka, J. Xie, and S. P. Lim, "A MEMS rotary comb mechanism for harvesting the kinetic energy of planar vibrations,” J. Micromech. Microeng. 20, 065017 (2010)

41. W. Ma, R. Zhu, L. Rufer, Y. Zohar, and M. Wong, "An integrated floating-electrode electric microgenerator," J. Micro Electro Mech. Syst. 16, 29-37 (2007)

42. Q. Yuan, X. Sun, D.-M. Fang, and H. Zhang, Design and microfabrication of integrated magnetic MEMS energy harvester for low frequency application, Paper presented in 16th International Conference on Solid-State Sensors, Actuators and Microsystems in Bijing China, IEEE 2, 1855-58 (2011)

43. T. Galchev, H. Kim, and K. Najafi, "Micro power generator for harvesting low-frequency and nonperiodic vibrations," J. Micro Electro Mech. Syst. 20, 852-866 (2011)

44. S. P. Beeby, M. J. Tudor, and N. White, "Energy harvesting vibration sources for microsystems applications," Meas. Sci. Technol. 17, R175-95 (2006)

45. S. Roundy, P. K. Wright, and J. Rabaey, "A study of low level vibrations as a power source for wireless sensor nodes," Comp. Commun. 26, 1131-1144

46. J. Briscoe and S. Dunn, "Piezoelectric nanogenerators - a review of nanostructured piezoelectric energy harvesters," Nano Energy. 14, 15-29 (2015)

47. Y. Hu and Z. L. Wang, "Recent progress in piezoelectric nanogenerators as a sustainable power source in self-powered systems and active sensors," Nano Energy. 14, 3-14 (2015)

48. I. Dakua and N. Afzulpurkar, "Piezoelectric energy generation and harvesting at the nano-scale: materials and devices," Nanomater. Nanotechnol. 3, 21 (2013)

49. Z. Lin, J. Chen, and J. Yang, "Recent progress in triboelectric nanogenerators as a renewable and sustainable power source," J. Nanomater. (2016).

50. Z. L. Wang, J. Chen, and L. Lin, "Progress in triboelectric nanogenerators as a new energy technology and self-powered sensors," Energy Environ. Sci. 8, 2250-2282 (2015)

51. Z. Gao, J. Zhou, Y. Gu, P. Fei, Y. Hao, G. 
Bao, and Z. L. Wang, "Effects of piezoelectric potential on the transport characteristics of metal-ZnO nanowire-metal field effect transistor,” J. Appl. Phys. 105 (11), 113707 (2009).

52. Z. L. Wang, "Energy Harvesting Using Piezoelectric Nanowires - A Correspondence on "Energy Harvesting Using Nanowires?" by Alexe et al," Adv. Mater. 21, 1311-1315 (2009)

53. Z. L. Wang, R. Yang, J. Zhou, Y. Qin, C. Xu, Y. Hu, and S. Xu, "Lateral nanowire/nanobelt based nanogenerators, piezotronics and piezophototronics," Mater. Sci. Eng. R Rep. 70, 320-329 (2010)

54. K. Y. Lee, M. K. Gupta, and S.-W. Kim, "Transparent flexible stretchable piezoelectric and triboelectric nanogenerators for powering portable electronics," Nano Energy. 14, 139160 (2015)

55. E. Nour, O. Nur, and M. Willander, "Zinc oxide piezoelectric nano-generators for low frequency applications," Semicond. Sci. Technol. 32, 064005 (2017)

56. K.-I. Park, S. Xu, Y. Liu, G.-T. Hwang, S.-J. L. Kang, Z. L. Wang, and K. J. Lee, "Piezoelectric BaTiO3 thin film nanogenerator on plastic substrates," Nano. Lette. 10, 49394943 (2010)

57. Z. -H. Lin, Y. Yang, J. M. Wu, Y. Liu, zF. Zhang, and Z. L. Wang, "BaTiO3 nanotubesbased flexible and transparent nanogenerators, ” J. Phys. Chem. Lett. 3, 3599-3604 (2012)

58. K. I. Park, M. Lee, Y. Liu, S. Moon, G. T. Hwang, G. Zhu, J. E. Kim, S. O. Kim, D. K. Kim, and Z. L. Wang, "Flexible nanocomposite generator made of BaTiO3 nanoparticles and graphitic carbons," Adv. Mater. 24, 29993004 (2012)

59. S. Gupta, A. Tanwar, R. Mukhiya, and S. S. Kumar, "Design and Simulations of $\mathrm{ZnO}-$ based Piezoelectric Energy Harvester," Paper presented in ISSS International Conference on Smart Materials, Structures and Systems in Bangalore, India, 5-7 July 2017,

60. Y. Xi, J. Song, S. Xu, R. Yang, Z. Gao, C. Hu, and Z. L. Wang, "Growth of $\mathrm{ZnO}$ nanotube arrays and nanotube based piezoelectric nanogenerators," J. Mater. Chem. 19, 92609264 (2009)

61. Y. Qiu, H. Zhang, L. Hu, D. Yang, L. Wang, B. Wang, J. Ji, G. Liu, X. Liu, and J. Lin, "Flexible piezoelectric nanogenerators based on $\mathrm{ZnO}$ nanorods grown on common paper substrates," Nanoscale 4, 6568-6573 (2012)

62. S. Xu, B. J. Hansen, and Z. L. Wang, "Piezoelectric-nanowire-enabled power source for driving wireless microelectronics," Nat. Commun. 1, 93 (2010)

63. J. Kwon, W. Seung, B. K. Sharma, S.-W. Kim, and J.-H. Ahn, "A high performance PZT ribbon-based nanogenerator using graphene transparent electrodes," Energy Environ. Sci. 5, 8970-8975 (2012)

64. C. Dagdeviren, B. D. Yang, Y. Su, P. L. Tran, P. Joe, E. Anderson, J. Xia, V. Doraiswamy, B. Dehdashti, and X. Feng, "Conformal piezoelectric energy harvesting and storage from motions of the heart, lung, and diaphragm," Proc. Natl. Acad. Sci. 111, 1927-1932 (2014)

65. C. Chang, V. H. Tran, J. Wang, Y.-K. Fuh, and L. Lin, "Direct-write piezoelectric polymeric nanogenerator with high energy conversion efficiency," Nano. Lett. 10, 726731 (2010)

66. B. J. Hansen, Y. Liu, R. Yang, and Z. L. Wang, "Hybrid nanogenerator for concurrently harvesting biomechanical and biochemical energy," ACS Nano. 4, 3647-3652 (2010)

67. L. Persano, C. Dagdeviren, Y. Su, Y. Zhang, S. Girardo, D. Pisignano, Y. Huang, and J. A. Rogers, "High performance piezoelectric devices based on aligned arrays of nanofibers of poly (vinylidenefluoride-cotrifluoroethylene)," Nat. Commun. 4, 1633 (2013).

68. X. Chen, H. Tian, X. Li, J. Shao, Y. Ding, N. An, and Y. Zhou, "A high performance $\mathrm{P}$ (VDF-TrFE) nanogenerator with selfconnected and vertically integrated fibers by patterned EHD pulling," Nanoscale 7, 1153611544 (2015) 
69. S. Cha, S. M. Kim, H. Kim, J. Ku, J. I. Sohn, Y. J. Park, B. G. Song, M. H. Jung, E. K. Lee, and B. L. Choi, "Porous PVDF as effective sonic wave driven nanogenerators," Nano. Lett. 11, 5142-5147 (2011)

70. Y. Mao, P. Zhao, G. McConohy, H. Yang, Y. Tong, and X. Wang, "Sponge-Like Piezoelectric Polymer Films for Scalable and Integratable Nanogenerators and SelfPowered Electronic Systems," Adv. Energy. Mater. 4, (2014)

71. B. Kumar and S.-W. Kim, "Recent advances in power generation through piezoelectric nanogenerators," J. Mater. Chem. 21, 1894618958 (2011)

72. T. Bateman, "Elastic moduli of single-crystal zinc oxide," J. Appl. Phys. 33, 3309-3312 (1962)

73. P. Gopal and N. A. Spaldin, "Polarization, piezoelectric constants, and elastic constants of $\mathrm{ZnO}, \mathrm{MgO}$, and CdO," J. Electron Mater. 35, 538-542 (2006)

74. R. F. Pierret, Semiconductor device fundamentals. 2nd edn (Addison Wesley, India, 1996) pp. 470-90

75. W. Park, G. - C. Yi, J. - W. Kim, and S. - M. Park, "Schottky nanocontacts on $\mathrm{ZnO}$ nanorod arrays," Appl. Phys. Lett. 82, 4358-4360 (2003)

76. R. Yang, Y. Qin, C. Li, G. Zhu, and Z. L. Wang, "Converting biomechanical energy into electricity by a muscle-movement-driven nanogenerator," Nano. Lett. 9, 1201-1205 (2009)

77. M. Lee, J. Bae, J. Lee, C.-S. Lee, S. Hong, and Z. L. Wang, "Self-powered environmental sensor system driven by nanogenerators," Energy. Environ. Sci. 4, 3359-3363 (2011)

78. K. H. Kim, K. Y. Lee, J. S. Seo, B. Kumar, and S. W. Kim, "Paper-based piezoelectric nanogenerators with high thermal stability," Small. 7, 2577-2580 (2011)

79. Y. Huang, X. Duan, Y. Cui, L. J. Lauhon, K. -H. Kim, and C. M. Lieber, "Logic gates and computation from assembled nanowire building blocks,” Science. 294, 1313-1317
(2001)

80. Z. Shao, X. Zhang, X. Wang, and S. Chang, "Electrical characteristics of Pt-ZnO Schottky nano-contact," Sci China Phys Mech. 53, 64-67 (2010)

81. J. Liu, P. Fei, J. Song, X. Wang, C. Lao, R. Tummala, and Z. L. Wang, "Carrier density and Schottky barrier on the performance of DC nanogenerator," Nano. Lett. 8, 328-332 (2008)

82. D. Davies, "Harmful effects and damage to electronics by electrostatic discharges," J. Electrostat. 16, 329-342 (1985)

83. F.-R. Fan, Z.-Q. Tian, and Z. L. Wang, "Flexible triboelectric generator," Nano Energy. 1, 328-334 (2012)

84. P. Shaw, "Experiments on tribo-electricity. I. -The tribo-electric series," Proc. R. Soc. Lond. A. 94, 16-33 (1917)

85. Z. L. Wang, "Towards self-powered nanosystems: from nanogenerators to nanopiezotronics," Adv. Func. Mater. 18, 3553-3567 (2008).

86. L. Lin, S. Wang, Y. Xie, Q. Jing, S. Niu, Y. $\mathrm{Hu}$, and Z. L. Wang, "Segmentally structured disk triboelectric nanogenerator for harvesting rotational mechanical energy," Nano. Lett. 13, 2916-2923 (2013)

87. D. Kim, Y. Oh, B.-W. Hwang, S.-B. Jeon, S. -J. Park, and Y.-K. Choi, "Triboelectric nanogenerator based on the internal motion of powder with a package structure design," ACS Nano 10, 1017-1024 (2015)

88. B. Meng, W. Tang, Z.-h. Too, X. Zhang, M. Han, W. Liu, and H. Zhang, "A transparent single-friction-surface triboelectric generator and self-powered touch sensor," Energy Environ. Sci. 6, 3235-3240 (2013)

89. Wang, S., L. Lin, and Z.L. Wang, "Triboelectric nanogenerators as self-powered active sensors." Nano Energy. 11, 436-462(2015).

90. Y. Zi, H. Guo, Z. Wen, M.-H. Yeh, C. Hu, and Z. L. Wang, "Harvesting low-frequency $(<5 \mathrm{~Hz})$ irregular mechanical energy: a possible killer application of triboelectric nanogenerator," ACS Nano. 10, 4797-4805 (2016) 
91. Z. L. Wang, L. Lin, J. Chen, S. Niu, and Y. Zi, "Triboelectric Nanogenerator: Vertical Contact-Separation Mode", in Triboelectric Nanogenerators (Springer, New York, 2016), 23-47 (2016)

92. S. Kim, M. K. Gupta, K. Y. Lee, A. Sohn, T. Y. Kim, K. S. Shin, D. Kim, S. K. Kim, K. H. Lee, and H. J. Shin, "Transparent flexible graphene triboelectric nanogenerators," Adv. Mater. 26, 3918-3925 (2014)

93. L. Dhakar, F. E. H. Tay, and C. Lee, "Development of a broadband triboelectric energy harvester with SU-8 micropillars," J. Micro Electro Mech. Syst 24, 91-99 (2015)

94. M. Dresselhaus and I. Thomas, "Alternative energy technologies," Nature. 414, 332-337 (2001)

95. Q. Zhang, C. S. Dandeneau, X. Zhou, and G. Cao, "ZnO Nanostructures for Dye-Sensitized Solar Cells," Adv. Mater. 21, 4087-4108 (2009)

96. F. J. DiSalvo, "Thermoelectric cooling and power generation," Science. 285, 703-706 (1999)

97. B. Poudel, Q. Hao, Y. Ma, Y. Lan, A. Minnich, B. Yu, X. Yan, D. Wang, A. Muto, and D. Vashaee, "High-thermoelectric performance of nanostructured bismuth antimony telluride bulk alloys," Science. 320, 634-638 (2008)

98. N. R. Alluri, A. Chandrasekhar, and S.-J. Kim, "Exalted Electric Output via PiezoTriboelectric Coupling/Sustainable Butterfly Wing Structure Type Multiunit Hybrid Nanogenerator," ACS Sustain. Chem. Eng. 6, 1919-1933 (2018)

99. M. Lee, R. Yang, C. Li, and Z. L. Wang, "Nanowire- Quantum Dot Hybridized Cell for Harvesting Sound and Solar Energies," The J. Phys. Chem. Lett. 1, 2929-2935 (2010)

100. M. Han, X. Zhang, W. Liu, X. Sun, X. Peng, and $\mathrm{H}$. Zhang, "Low-frequency wide-band hybrid energy harvester based on piezoelectric and triboelectric mechanism," Sci. China. Technol. Sci. 56, 1835-1841 (2013)

101. Chen Xu and Zhong Lin Wang, "Compact hybrid cell based on a convoluted nanowire structure for harvesting solar and mechanical energy," Adv. Mater. 23, 873-877 (2011)

102. C. Pan, W. Guo, L. Dong, G. Zhu, and Z. L. Wang, "Optical Fiber-Based Core-Shell Coaxially Structured Hybrid Cells for SelfPowered Nanosystems," Adv. Mater. 24, 3356-3361 (2012)

103. D. - Y. Lee, H. Kim, H. - M. Li, A. - R. Jang, Y.-D. Lim, S. N. Cha, Y. J. Park, D. J. Kang, and W. J. Yoo, "Hybrid energy harvester based on nanopillar solar cells and PVDF nanogenerator," Nanotechnology. 24, 175402 (2013)

104. Y. Yang, H. Zhang, Z.-H. Lin, Y. Liu, J. Chen, Z. Lin, Y. S. Zhou, C. P. Wong, and Z. L. Wang, "A hybrid energy cell for selfpowered water splitting," Energy Environ. Sci. 6, 2429-2434 (2013)

105. Y. Yang, H. Zhang, Y. Liu, Z.-H. Lin, S. Lee, Z. Lin, C. P. Wong, and Z. L. Wang, "Silicon-based hybrid energy cell for selfpowered electrodegradation and personal electronics," ACS Nano. 7, 2808-2813 (2013)

106. S. -B. Jeon, D. Kim, G.-W. Yoon, J.-B. Yoon, and Y.-K. Choi, "Self-cleaning hybrid energy harvester to generate power from raindrop and sunlight," Nano Energy. 12, 636-645 (2015)

107. L. Zheng, G. Cheng, J. Chen, L. Lin, J. Wang, Y. Liu, H. Li, and Z. L. Wang, "A hybridized power panel to simultaneously generate electricity from sunlight, raindrops, and wind around the clock," Adv. Energy. Mater. 5, 1501152 (2015)

108. Y. Fang, J. Tong, Q. Zhong, Q. Chen, J. Zhou, Q. Luo, Y. Zhou, Z. Wang, and B. Hu, "Solution processed flexible hybrid cell for concurrently scavenging solar and mechanical energies," Nano Energy. 16, 301-309 (2015)

109. H. Guo, Z. Wen, Y. Zi, M. H. Yeh, J. Wang, L. Zhu, C. Hu, and Z. L. Wang, "A WaterProof Triboelectric-Electromagnetic Hybrid Generator for Energy Harvesting in Harsh Environments," Adv. Energy. Mater. 6, (2016)

110. H. Zhong, Z. Wu, X. Li, W. Xu, S. Xu, S. Zhang, Z. Xu, H. Chen, and S. Lin, "Graphene based two dimensional hybrid 
nanogenerator for concurrently harvesting energy from sunlight and water flow," Carbon. 105, 199-204 (2016)

111. Semsudin, N.A.A., et al., "Integrated hybrid micro energy harvester based on thermal and vibration using op-amp for biomedical devices". Asian J. Sci. Res. 10, 34-42 (2017)

112. Jiang, C., et al., "Enhanced Solar Cell Conversion Efficiency of InGaN/GaN Multiple Quantum Wells by Piezo-Phototronic Effect”. ACS Nano. 11, 9405-9412 (2017).

113. You, M.-H., et al., "Self-Powered Flexible Hybrid Piezoelectric-Pyroelectric Nanogenerator based on Non-woven Nanofiber Membranes". J. Mater. Chem. A. 6, 3500-3509 (2018)

114. Vivekananthan, V., et al., "A sliding mode contact electrification based triboelectricelectromagnetic hybrid generator for smallscale biomechanical energy harvesting," Micro and Nano Syst Lett. 7, 1-8 (2019)

115. H. Kim, S. Priya, H. Stephanou, and K. Uchino, "Consideration of impedance matching techniques for efficient piezoelectric energy harvesting," IEEE transactions on ultrasonics, IEEE. T. Ultrason. Ferr. 54, (2007)

116. J. Briscoe, N. Jalali, P. Woolliams, M. Stewart, P. M. Weaver, M. Cain, and S. Dunn, "Measurement techniques for piezoelectric nanogenerators," Energy Environ. Sci. 6, 3035-3045 (2013)

117. S. Niu, Y. S. Zhou, S. Wang, Y. Liu, L. Lin, Y. Bando, and Z. L. Wang, "Simulation method for optimizing the performance of an integrated triboelectric nanogenerator energy harvesting system," Nano Energy. 8, 150-156 (2014)

118. C. Zhang, W. Tang, C. Han, F. Fan, and Z. L. Wang, "Theoretical comparison, equivalent transformation, and conjunction operations of electromagnetic induction generator and triboelectric nanogenerator for harvesting mechanical energy," Adv. Mater. 26, 35803591 (2014).

119. H. Yamazaki and T. Kitayama, "Pyroelectric properties of polymer-ferroelectric composites," Ferroelectrics. 33, 147-153 (1981)

120. Q. Leng, L. Chen, H. Guo, J. Liu, G. Liu, C. $\mathrm{Hu}$, and $\mathrm{Y} . \mathrm{Xi}$, "Harvesting heat energy from hot/cold water with a pyroelectric generator," J. Mater. Chem. A. 2, 11940-11947 (2014)

121. D. Zhu, M. J. Tudor, and S. P. Beeby, "Strategies for increasing the operating frequency range of vibration energy harvesters: a review," Meas Sci. Technol. 21, 022001 (2009)

122. X. Wang, S. Niu, F. Yi, Y. Yin, C. Hao, K. Dai, Y. Zhang, Z. You, and Z. L. Wang, "Harvesting ambient vibration energy over a wide frequency range for self-powered electronics," ACS Nano. 11, 1728-1735 (2017)

123. S. Chen, X. Tao, W. Zeng, B. Yang, and S. Shang, "Quantifying Energy Harvested from Contact-Mode Hybrid Nanogenerators with Cascaded Piezoelectric and Triboelectric Units," Adv. Energy. Mater. 7, (2017)

124. Wang, X., et al. "Flexible triboelectric and piezoelectric coupling nanogenerator based on electrospinning $\mathrm{P}(\mathrm{VDF}-\mathrm{TRFE})$ nanowires. Paper presented in 28th International Conference on Micro Electro Mechanical Systems in Estoril," Portugal. IEEE (110-13) 2015

125. Y. Yang, H. Zhang, S. Lee, D. Kim, W. Hwang, and Z. L. Wang, "Hybrid energy cell for degradation of methyl orange by selfpowered electrocatalytic oxidation," Nano Lett. 13, 803-808 (2013)

126. L. S. McCarty and G. M. Whitesides, "Electrostatic charging due to separation of ions at interfaces: contact electrification of ionic electrets," Angew. Chem. 47, 2188-2207 (2008)

127. M. Han, X. Chen, B. Yu, and H. Zhang, “ Coupling of piezoelectric and triboelectric effects: From theoretical analysis to experimental verification," Adv. Electron. Mater. 1, (2015)

128. J. Zhu, X. Hou, X. Niu, X. Guo, J. Zhang, J. He, T. Guo, X. Chou, C. Xue, and W. Zhang, "The d-arched piezoelectric-triboelectric 
hybrid nanogenerator as a self-powered vibration sensor," Sens. Actuators A. Phys. 263, 317-325 (2017)

129. Wu, Y., et al., "Flexible composite-nanofiber based piezo-triboelectric nanogenerators for wearable electronics.” J. Mater. Chem. A. 7, 13347-13355 (2019)

130. Li, M., et al., "All-in-one cellulose based hybrid tribo/piezoelectric nanogenerator." Nano. Res. 12, 1831-1835 (2019)

131. Lapčnskis, L., et al., "Hybrid Tribo-PiezoElectric Nanogenerator with Unprecedented Performance Based on Ferroelectric Composite Contacting Layers.” ACS Appl. Energy Mater. 2, 4027-4032 (2019)

132. Chung, J., et al., "Hand-Driven Gyroscopic Hybrid Nanogenerator for Recharging Portable Devices.” Adv. Sci. 5, 1801054 (2018)

133. H. Kim, S. M. Kim, H. Son, H. Kim, B. Park, J. Ku, J. I. Sohn, K. Im, J. E. Jang, and J.-J. Park, "Enhancement of piezoelectricity via electrostatic effects on a textile platform," Energy Environ. Sci. 5, 8932-8936 (2012)

134. C. Xue, J. Li, Q. Zhang, Z. Zhang, Z. Hai, L. Gao, R. Feng, J. Tang, J. Liu, and W. Zhang, "A novel arch-shape nanogenerator based on piezoelectric and triboelectric mechanism for mechanical energy harvesting," Nanomaterials. 5, 36-46 (2014)

135. Q. Nguyen, B. H. Kim, and J. W. Kwon, "Paper-based $\mathrm{ZnO}$ nanogenerator using contact electrification and piezoelectric effects," Journal of Microelectromechanical Systems 24, 519-521 (2015)

136. T. Huang, C. Wang, H. Yu, H. Wang, Q. Zhang, and M. Zhu, "Human walking-driven wearable all-fiber triboelectric nanogenerator containing electrospun polyvinylidene fluoride piezoelectric nanofibers," Nano Energy. 14, 226-235 (2015)

137. P. Bai, G. Zhu, Y. S. Zhou, S. Wang, J. Ma, G. Zhang, and Z. L. Wang, "Dipole-momentinduced effect on contact electrification for triboelectric nanogenerators," Nano Res. 7, 990-997 (2014)

138. G. Romano, G. Mantini, A. Di Carlo, A.
D’Amico, C. Falconi, and Z. L. Wang, "Piezoelectric potential in vertically aligned nanowires for high output nanogenerators," Nanotechnology. 22, 465401 (2011)

139. X. Li, Z.-H. Lin, G. Cheng, X. Wen, Y. Liu, S. Niu, and Z. L. Wang, "3D fiber-based hybrid nanogenerator for energy harvesting and as a self-powered pressure sensor," ACS Nano. 8, 10674-10681 (2014)

140. Zhao, C., et al., "Hybrid piezo/triboelectric nanogenerator for highly efficient and stable rotation energy harvesting." Nano Energy. 57, 440-449 (2019)

141. Chen, C., et al., A fully encapsulated piezoelectric-triboelectric hybrid nanogenerator for energy harvesting from biomechanical and environmental sources. Express Polym. Lett. 13, 533-542 (2019)

142. Y. Zhu, B. Yang, J. Liu, X. Wang, X. Chen, and C. Yang, "An integrated flexible harvester coupled triboelectric and piezoelectric mechanisms using PDMS/MWCNT and PVDF," J. Microelectromech. S. 24, 513-515 (2015)

143. H. Li, L. Su, S. Kuang, Y. Fan, Y. Wu, Z. L. Wang, and G. Zhu, "Multilayered flexible nanocomposite for hybrid nanogenerator enabled by conjunction of piezoelectricity and triboelectricity," Nano. Res. 10, 785-793 (2017)

144. G. Hassan, F. Khan, A. Hassan, S. Ali, J. Bae, and C. H. Lee, "A flat-panel-shaped hybrid piezo/triboelectric nanogenerator for ambient energy harvesting," Nanotechnology. 28, 175402 (2017)

145. Jirayupat, C., et al.,"Piezoelectric-Induced Triboelectric Hybrid Nanogenerators Based on the $\mathrm{ZnO}$ Nanowire Layer Decorated on the $\mathrm{Au} /$ polydimethylsiloxane-Al Structure for Enhanced Triboelectric Performance", ACS Appl. Mater. Interfaces. 10, 6433-6440 (2018).

146. Y. Xie, S. Wang, L. Lin, Q. Jing, Z. - H. Lin, S. Niu, Z. Wu, and Z. L. Wang, "Rotary triboelectric nanogenerator based on a hybridized mechanism for harvesting wind energy," ACS Nano. 7, 7119-7125 (2013) 
147. L. Zhang, B. Zhang, J. Chen, L. Jin, W. Deng, J. Tang, H. Zhang, H. Pan, M. Zhu, and W. Yang, "Lawn structured triboelectric nanogenerators for scavenging sweeping wind energy on rooftops," Adv. Mater. 28, 16501656 (2016)

148. T. Chen, Y. Xia, W. Liu, H. Liu, L. Sun, and C. Lee, "A hybrid flapping-blade wind energy harvester based on vortex shedding effect," J. Microelectromech. S. 25, 845-847 (2016)

149. F. -R. Fan, L. Lin, G. Zhu, W. Wu, R. Zhang, and Z. L. Wang, "Transparent triboelectric nanogenerators and self-powered pressure sensors based on micropatterned plastic films," Nano. Lett. 12, 3109-3114 (2012)

150. C. K. Jeong, K. M. Baek, S. Niu, T. W. Nam, Y. H. Hur, D. Y. Park, G.-T. Hwang, M. Byun, Z. L. Wang, and Y. S. Jung, "Topographically-designed triboelectric nanogenerator via block copolymer selfassembly," Nano. Lett. 14, 7031-7038 (2014)

151. P. Bai, G. Zhu, Q. Jing, J. Yang, J. Chen, Y. Su, J. Ma, G. Zhang, and Z. L. Wang, "Membrane-Based Self-Powered Triboelectric Sensors for Pressure Change Detection and Its Uses in Security Surveillance and Healthcare
Monitoring," Adv. Func. Mater. 24, 58075813 (2014)

152. W. Yang, J. Chen, G. Zhu, J. Yang, P. Bai, Y. Su, Q. Jing, X. Cao, and Z. L. Wang, "Harvesting energy from the natural vibration of human walking," ACS Nano. 7, 1131711324 (2013)

153. X. Yang and W. A. Daoud, "Synergetic effects in composite-based flexible hybrid mechanical energy harvesting generator," J. Mater. Chem. A. 5, 9113-9121 (2017)

154. Y. Qian, D .J .Kang, "Poly(dimethylsiloxane)/ $\mathrm{ZnO}$ nanoflakes/three-dimensional graphene heterostructures for high-performance flexible energy harvesters with simultaneous piezoelectric triboelectric generation," ACS Appl. Mater. Interfaces 10, 32281-32288 (2018)

155. W. He, Y. Qian, B. S. Lee, F. Zhang, A. Rasheed, J. E. Jung, D. J. Kang, "Ultrahigh Output Piezoelectric and Triboelectric Hybrid Nanogenerators Based on ZnO Nanoflakes/ Polydimethylsiloxane Composite Films," ACS Appl. Mater. Interfaces 2018, 10, 4441544420 (2018) 


\section{특 집 ㅍ Aamir Rasheed, 박현제, 손민균, 이태형, 강대준}
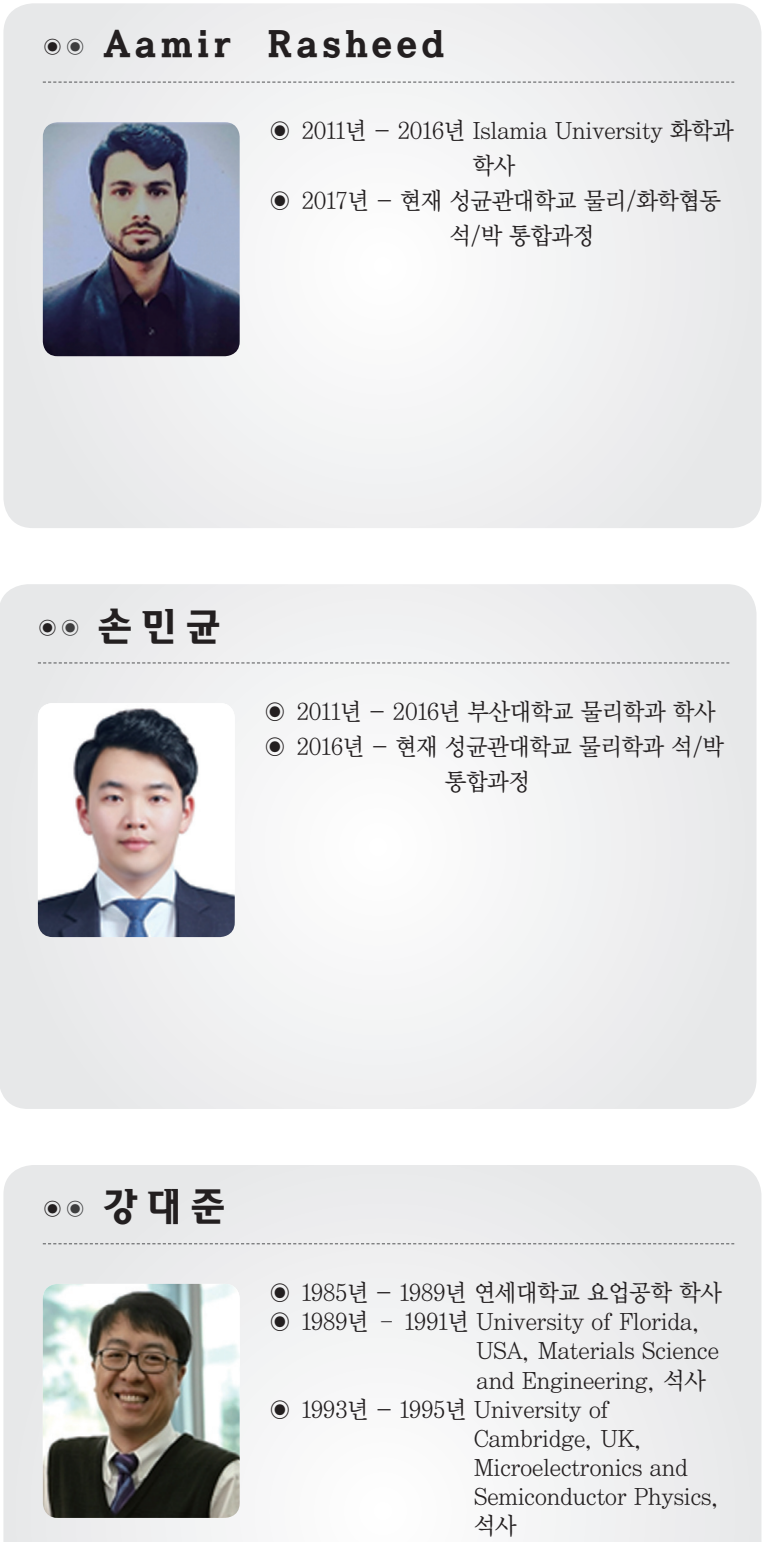

( 1985년 - 1989년 연세대학교 요업공학 학사

○ 1989년 - 1991년 University of Florida, USA, Materials Science and Engineering, 석사

○ 1993년 - 1995년 University of Cambridge, UK,

Microelectronics and Semiconductor Physics, 석사 ㅇ 1995년 - 1999년 University of Cambridge,
UK, Physics, 박사

- 2005년 - 2009년 성균관대학교 물리학과 조교수

○ 2009년 - 2013년 성균관대학교 물리학과 부교수

- 2013년 - 2015년 성균관대학교 물리학과

- 2015년 - 현재 성균관대학교 물리학과 정교수

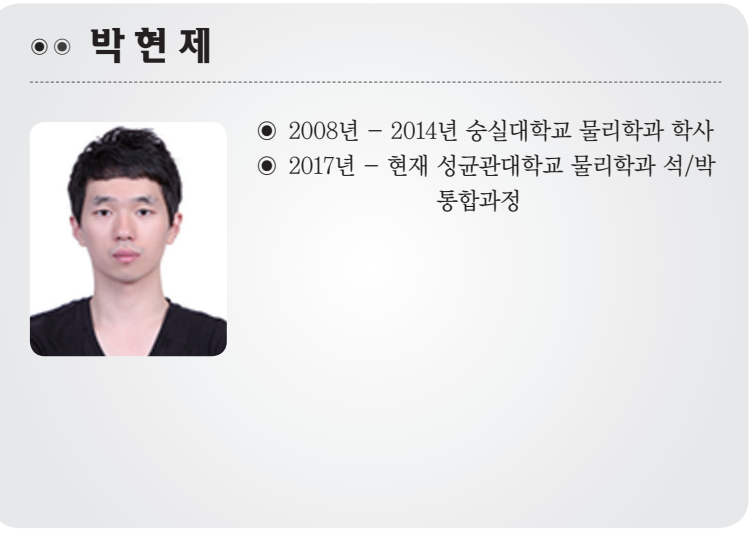

○○이 태 형

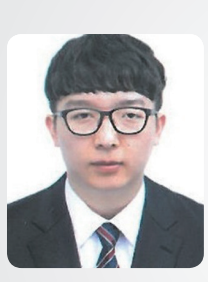

- 2011년 - 2017년 강릉원주대학교 물리학과 학사

- 2019년 - 현재 성균관대학교 물리학과 석/박 통합과정 